Florida International University FIU Digital Commons

$3-31-2000$

\title{
Picking up the pieces: body parts and female power in Shakespeares The rape of Lucrece
}

Daphne Blum

Florida International University

DOI: $10.25148 /$ etd.FI14051173

Follow this and additional works at: https://digitalcommons.fiu.edu/etd

Part of the Literature in English, British Isles Commons, and the Other Feminist, Gender, and Sexuality Studies Commons

\section{Recommended Citation}

Blum, Daphne, "Picking up the pieces: body parts and female power in Shakespeare's The rape of Lucrece" (2000). FIU Electronic Theses and Dissertations. 1714.

https://digitalcommons.fiu.edu/etd/1714 


\section{FLORIDA INTERNATIONAL UNIVERSITY}

Miami, Florida

\section{PICKING UP THE PIECES: BODY PARTS AND FEMALE POWER IN SHAKESPEARE'S THE RAPE OF LUCRECE}

A thesis submitted in partial fulfillment of the requirements for the degree of

MASTER OF ARTS

in

ENGLISH

by

Daphne Blum 
To: Dean Arthur W. Herriott

College of Arts and Sciences

This thesis, written by Daphne Blum, and entitled Picking Up the Pieces: Body Parts and Female Power in Shakespeare's The Rape of Lucrece, having been approved in respect to style and intellectual content, is referred to you for judgment.

We have read this thesis and recommend that it be approved.

Dr. James Sutton

Dr. Donald Watson

Dr. Peggy Endel, Major Professor

Date of Defense: March 31, 2000

The thesis of Daphne Blum is approved.

Dean Arthur W. Herriott College of Arts and Sciences

Dean Richard L. Campbell Division of Graduate Studies

Florida International University, 2000 


\section{DEDICATION}

This work is dedicated to my parents, to my brothers, and especially to my fiance,

Rony. Thank you for your support, your love, and your laughter-all of which helped me keep my sanity during this process. 


\section{ACKNOWLEDGMENTS}

I wish to thank the members of my committee for their time, support, and suggestions. I would especially like to thank my major professor, Dr. Peggy

Endel, who not only remained umbilically-tied to me via email, but who helped me maintain confidence in my abilities. I know this semester was difficult, so I thank you whole-heartedly for all the time you invested. 


\section{ABSTRACT OF THE THESIS SHAKESPEARE'S THE RAPE OF LUCRECE \\ by \\ Daphne Blum \\ Florida International University, 2000 \\ Miami, Florida \\ Professor Peggy Endel, Major Professor}

PICKING UP THE PIECES: BODY PARTS AND FEMALE POWER IN

In The Rape of Lucrece, Shakespeare anatomizes Lucrece's body-fragments the whole, splits apart the parts. He does so not only to expose the otherwise concealed act of rape-which is hidden within the mysterious and "invisible" female genitalia-but to indicate that Lucrece's parts, through analogy with Pagan and Christian figures and theories, are powerful, even combative, but always pure.

In the first section, individual body parts connect Lucrece with so-called "wild women," including the Amazons, Medusa, and Philomela. In the second section, body parts either link Lucrece, or sever Tarquin, from the Divine. In the final section, Classical Mythology and Protestantism conflate in the dis-embodied figure of Helen of Troy. The body-Lucrece's, Tarquin's and the figures on the tapestry-is explored in metaphorical parts, dismembered, or apotheosized/de-corporealized in an attempt to prove that a raped woman may retain her subjectivity along with her innocence. 


\section{TABLE OF CONTENTS}

CHAPTER

PAGE

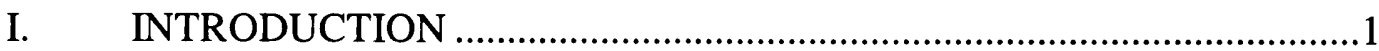

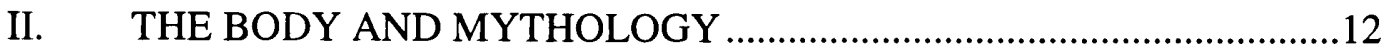

The Amazonian Breast........................................................................13

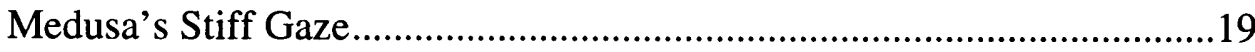

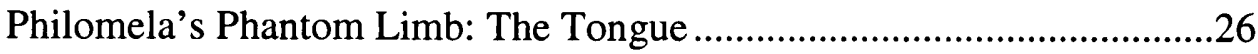

Synecdoche, Ekphrasis and the Tapestry ……….....................................46

III. THE BODY AND RELIGION: LUCRECE'S “CRUCIFIXION”..............54

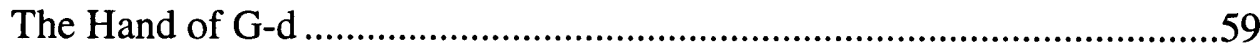

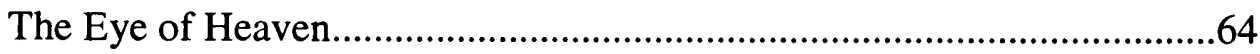

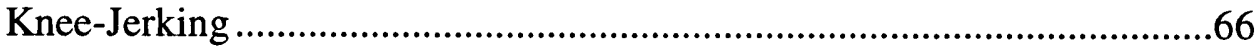

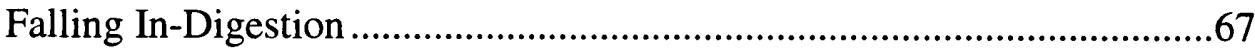

IV. THE DISEMBODIED HELL/EN OF TROY ...........................................

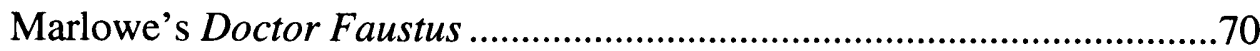

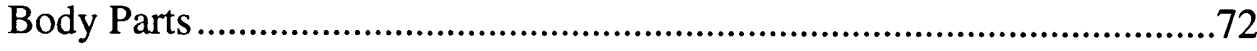

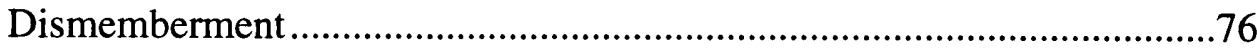

The Demonization of Helen: Dishonor/Disembodiment ...........................81

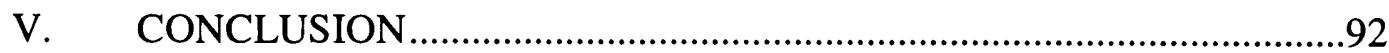

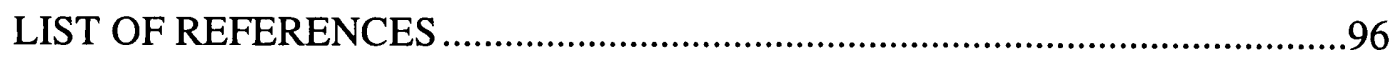


For much imaginary work was there,-

Conceit deceitful, so compact, so kind,

That for Achilles' image stood his spear

Gripp'd in an armed hand; himself behind

Was left unseen, save to the eye of mind:

A hand, a foot, a face, a leg, a head

Stood for the whole to be imagined.

(Shakespeare, The Rape of Lucrece 1422-428)

\section{Introduction}

By analyzing Shakespeare's emendation of his sources-Livy's The History of Rome from its Foundation, Ovid's Fasti, Chaucer's The Legend of Good Women, and Daniel's The Complaint of Rosamond-it becomes apparent how much he endeavored to endow his protagonist with a sense of power in his 1594 poem The Rape of Lucrece. Shakespeare worked against a tradition which deftly underscored Lucrece's feebleness to use her as a symbol of political corruption, womanly virtue, and/or as proof of her innocence-rape narratives of the period often strip the victim of subjectivity, for an objectified "weak woman" cannot be held accountable.

Shakespeare's incessant visual references, on the other hand, imply that he desired to dramatize his poem so that his Elizabethan audience could "see" Lucrece, not as a stock-character, object or commodity, but as a woman who can retain her innocence even as an individual. The poem, composed when the London theatres were closed due to the Black Plague, seems to long for the stage-for the power of visual representation of the body. A plethora of critics, attempting to find meaning in what they deem a senseless act of self-destruction, argue that Lucrece's suicide came out of a sense of guilt because, during the rape, her body yielded to some form of pleasure. This theory, however, conflicts with what Shakespeare labored adroitly to express. Body parts, in the 
Renaissance, were believed to be thinking, subjective beings, and Lucrece's partsthrough analogy, with Pagan and Christian figures and theories-are powerful, even combative, but always pure. Shakespeare anatomizes Lucrece's body in parts, then, to expose an otherwise undetectable crime, and to prove that a woman need not be weak to retain her innocence.

Shakespeare obtained the plot for The Rape of Lucrece, in part, from Livy's story of the expulsion of the Tarquins and the establishment of the Republic which appears in Book One of The History of Rome from its Foundation (24 B.C.), under the subcategory "Brutus the Liberator." Though Livy's is a chronicled account and Shakespeare's a tragic poem, the classical and renaissance versions parallel each other in that both not only document a pseudo-historical figure, but also create a portrait of a persona, a character. According to R.M. Ogilvie, part of Livy's appeal is his ability to "see history in terms of human characters and representative individuals. ... Instead of a barren list of unconnected events Livy constructs a series of moral episodes which are designed to bring out the character of the leading figures" (Livy 8-9).

However, Shakespeare emended his source by recruiting a new protagonist. Shakespeare's tale revolves not around Brutus, the victor-as Livy's does-but around Lucrece, the victim. Shakespeare's focus is not on political, but personal, renewal. In Livy's hands the tale explores triumph over political tyranny-in fact Livy's nationalism is overt in his celebration of Rome's virtues, and his admonition against her vices. Livy, who wavered "between pessimism and optimism, between the evils of modern Rome and the dawning of a Golden Age" (Livy 10), sought to educate his fellow Romans: "in history you have a record of the infinite variety of human experience plainly set out for 
all to see; and in that record you can find for yourself and your country both examples and warnings; fine things to take as models, base things rotten through and through, to avoid" (Livy 10). In Shakespeare's hands the tale explores, instead, the triumph over patriarchal tyranny. Hence, while the former investigates the male political body, the latter investigates the female physical body.

Ovid is a constant through out Shakespeare's works, and Lucrece is no exception. Ovid's Fasti (8 A.D.) charts, in calendar format, the Roman holidays: Lucrece and the creation of the Republic are celebrated on the $24^{\text {th }}$ of February. In Shakespeare's refusal to veil Lucrece he worked directly against Ovid. In the Fasti, Lucrece "kept still for a long time, modestly veiling her face" (819), and upon stabbing herself and "on the point of death, she made sure her collapse / was not unseemly_her last concern as she fell" (833-34). The concealment of her face and body is meant to be indicative of her virtue. ${ }^{1}$ Yet it is, for one, a farcical portrait of a self-obsessed woman who even in death succumbs to over-inflated, male-perpetuated, gender roles, and for another, it hints at the possibility that Lucrece has something she seeks to shroud beneath that veil.

Consequently, she is at once laughably dainty and suggestively culpable. Ironically, in Ovid she is dubbed, "The wife with the courage of a man" (847), but one cannot help but question how, at least in his version, she procured such honor.

Geoffrey Chaucer's The Legend of Good Women (1386), like Shakespeare's poem, emphasizes Lucrece's role; the fact that her rape catalyzed the exile of the kings is marginalized:

\footnotetext{
${ }^{1}$ Virtue, according to Anthony B. Dawson, is "what the Italians called virtu" and which ironically denotes "personal and military power" [Marlowe, Tamburlaine xvii].)
} 
Now I must tell of kings sent to exile

From Rome, because their actions were so vile,

And of the last king, call Tarquinius,

But not for that cause do I tell this story,

But for the praise and the remembered glory

Of that true wife Lucrece ... (1680-86)

Chaucer's Lucrece, however, is assumed to be chaste from the onset simply because she has been included in a catalogue of "Good Women." And, though Chaucer's omission of segments of the myth would seem to efface any doubt as to her virtue, those omissions and the company in which she finds herself-Dido and Medea to name two-only further the satire. As Nagle elucidates, because Chaucer's narrator is simply untrustworthy the entire work emanates a sense of mockery (Chaucer 9). In Shakespeare, on the contrary, there is little room for the travesty he allows in Venus and Adonis. Shakespeare vindicates Lucrece—not by allowing her a place in the hall of catalogued fame, so to speak-but by exploring her individual thoughts, fears, and manner of mourning.

While in Shakespeare's poem Lucrece dies surrounded by Roman men, Rosamond, of Samuel Daniel's complaint poem The Complaint of Rosamond (1594), will die alone. Rosamond says the queen "leauves m'alone, of all the world forfaken, / Except of Death, which fhe had left with me" (633-34). To die alone is to die without voice: "thy wrongs vnfeene, thy tale vntold, / Muft here in fecret filence buried lie. / And with thee, thine excufe together die" (661-63).. Unlike Lucrece, whose rape and body was exposed-in that it was carried through out the streets of Rome-Rosamond remains, literally, behind closed doors. While Lucrece complains to the Roman men, Rosamond must complain to the walls, to the air, and to herself: "Yet breathe out to thefe Walles the breath of mone, / Tell th'Aire thy plaints, fince men thou canft not tell. / . . . And be thy 
felfe the mourner and the corfe" (666-72). It is feasible that by secluding Rosamond, Daniel intended to indicate that she was accountable for her own demise. The sin is private and should remain hidden. Shakespeare, on the contrary, resolved for Lucrece to be absolved of all guilt. Exposing her to Roman society, and to his readers, does not compromise the opinion of her; quite the contrary, the fact that everything is brought into the light only underscores her inculpability—she has, Shakespeare seems to say, nothing to hide.

Moreover, the martial metaphors used in Rosamond demonstrate that in a man's world, beauty and hence the most "beautiful" of enclosures, cannot be protected by a woman's weak prayers and hands:

There whereas fraile and tender beauty ftands, With all affaulting powres inuironed; Hauing but prayers and weake feeble hands To hold their honours Fort vnuanquifhed. (99-102)

Rosamond relies upon the fragility of her sex, as a defense of her behavior, throughout the complaint. She never truly condemns herself for her actions since she refuses to see herself as an agent or subject. Rather, she reproaches the weakness that is characteristic of womanhood. To "ftand, and be vnconquered," she declares, "Is to b'aboue the nature of our kinde" (103-04). Lucrece, at times, uses the same rationale-that women cannot be held accountable because of the fundamental weakness of their sex-however, she seems only to do so when in the presence of Roman men, be it Tarquin or the entourage at the end of the poem. Rosamond, who is chargeable-who was not physically forced, simply persuaded - uses the notion in order to convince herself otherwise. She tries to clear herself in her own eyes. Lucrece, on the other hand, who is not at fault-and most likely 
knows so-understands, nevertheless, the constrictions of her sex, so she cunningly uses those same male-enacted codes to absolve herself of guilt in their eyes.

It may be arduous for a first-time reader of Lucrece to identify the subtle differences between Shakespeare's version and the versions of his sources. After all, Shakespeare's narrator also remarks that women cry effortlessly- "Their gentle sex to weep are often willing" (1236)—and claims that they are not flagitious, since they are only the wax into which men's evils are stamped:

For men have marble, women waxen, minds, And therefore are they form' $d$ as marble will; The weak oppress'd, th'impression of strange kinds Is form' $\mathrm{d}$ in them by force, by fraud, or skill. Then call them not the authors of their ill,

No more than wax shall be accounted evil, Wherein is stamp'd the semblance of a devil. (1240-246)

In upholding women as faultless, the narrator eradicates any indication of subjectivity. It is only through their objectification that women may be upheld as irreproachable:

Not that devour'd, but that which doth devour

Is worthy blame; $O$ let it not be hild

Poor women's faults, that they are so fulfill'd

With men's abuses! those proud lords to blame

Make weak-made women tenants to their shame. (1256-260)

Lucrece will also objectify herself through the same means, by relying upon her womanly weakness as a defense-“"'Mine enemy was strong, my poor self weak, / And far the weaker with so strong a fear" (1646-647).

However, Lucrece presumably only does so in order to prove her innocence, because as a subject, as an independent being, she can be held accountable. Therefore, she depends, consciously, on socially-ascribed gender roles to uphold her faultlessness. She likens herself to a commodity which has been stolen- "But thou shalt know thy 
int'rest was not bought / Basely with gold, but stol'n from forth thy gate" (1067-68)_ because she is aware that the men take pride in owning their women as possessions. Again, to establish her innocence in their eyes, Lucrece's self-portrayal, at least in their presence, must correspond with their stereotypical expectations of woman.

Therefore, in our modern-day conceptions, even Shakespeare's Lucrece may appear feeble. His Lucrece is also subject to patriarchy, as for example, when father and husband vie for her possession. Both claim she belonged to them. While Collantine declares "'she was my wife; / I ow'd her, and 'tis mine that she hath kill'd"' ([emphasis added] 1802-803), her father, Lucretius, exclaims, “'That life was mine which thou hast here deprived" ([emphasis added] 1751-752). Lucretius further objectifies his daughter by likening her to a mirror. While alive, he saw his youth in her; now deceased, he only sees his demise: "In thy sweet semblance my old age new-born; / But now that fair fresh mirror, dim and old, / Shows me a bare-bon'd death by time outworn" (1759-761). As a mirror Lucrece is only a reflection of others, not an autonomous being of her own. Her "I" reflects only another's "eye."

Furthermore, there are numerous references to encircled cities in The Rape of Lucrece which, among other things, have led critics to focus on the poem's political significance. Indeed, the poem begins with—and relies incessantly upon—the clichéd connection between the violent nature of desire and the penetration of a city, particularly important during England's rule by the virgin, i.e., inaccessible, queen:

His hand that yet remains upon her breast,Rude ram, to batter such an ivory wall!-

This moves him more rage and lesser pity,

To make the breach and enter this sweet city. (463-69) 
The grotesque denouement of the poem seems to serve as a warning to Queen Elizabeth (or to England) that she/it is just as vulnerable. When Brutus draws the knife from Lucrece's body, her blood divides:

In two slow rivers, that the crimson blood Circles her body in on every side, Who like a late-sack'd island vastly stood Bare and unpeopled in this fearful flood. (1737-741)

Not only has Lucrece become an island encircled by her own blood; she is in the flesh, has been laid bare-she is "bare and unpeopled."

Focusing on such political aspects of the myth of Lucrece puts the protagonist in danger of becoming a symbol; she becomes merely a tool, a means to attain an end. According to Ian Donaldson's The Rapes of Lucretia: A Myth and its Transformations, to focus on Lucrece's body merely as a martial symbol is potentially dangerous since it may only serve to catalyze her objectification:

The symbolic equations [between the rape of a country and the rape of a woman] lend the story a certain symmetry, yet at the same time possibly diminish it in human terms. By converting a woman into a symbol ... you may partly obscure the fact that her story is actually a dispiriting one, her real sphere of activity sharply delimited. It is through women, writes Simone de Beauvoir, that certain historical 'events have been set off, but the women have been pretexts rather than agents. The suicide of Lucretia has had value only as a symbol.' The agent in this story is a man, Brutus; Lucretia, the woman, merely suffers. (9-10)

Shakespeare, however, would not have spent such an exorbitant amount of time on Lucrece if he intended her only to serve as a symbol. So, while some "saw the story as primarily political in meaning ... sometimes curtly dismissing what an eighteenthcentury English adaptor called 'that excrescent Action of Lucretia' as marginal to the main point and interest of the story" (Donaldson 9), Shakespeare did not view it so. 
Though undeniably bookended by the Roman men's martial/political bravado, Lucrece's pith is dedicated to an exploration not of the men, but of one woman. The poem's title indicates its focus. The act of rape sets the poem in motion, but it is how Lucrece (and Shakespeare) deal with the rape that is of the utmost consequence. The poem is an exploration into the mind and body of the rape victim, and hence, at the center of the poem is Lucrece's exposed mind and body, spliced open for the viewer's gaze.

Critics have argued that Shakespeare's Lucrece is a product of a Western, patriarchal society, and that her suicide affirms her internalization of guilt and powerlessness. However, it should be noted that Shakespeare used a narrative not his own; the plot for Lucrece was borrowed, as was the format of the complaint poem. Focus, then, should remain not on plot, but in the way Shakespeare worked around the plot. For example, no matter how victimized she is by her position, Lucrece asserts-albeit, when alone-"For me, I am mistress of my fate" (1069). This colossal sentiment of female power guides her refusal of the maid's sympathy: "If thou dost weep for grief of my sustaining, / Know, gentle wench, it small avails my mood" (1272-273). She is, no doubt, being melodramatic, but it is also a sign of her new found autonomy from sociallyascribed gender roles. She will not merely weep pathetically with another woman; instead she will take a more courageous mode of action. No matter how critics work against her, Shakespeare's Lucrece is not merely the woman who suffered. In fact, it is Shakespeare's portrayal of Lucrece not as "a passive, wronged woman . . . but a powerful person who resists evil" (210), Bromley argues, that sets him apart from his contemporaries: [Shakespeare] deviates radically from the assumptions about women and morality which underlie other 'complaints' of the period. . . .In the complaints by Shakespeare's contemporaries, like Thomas Lodge's 
complaint of Elstred, Anthony Chute's Beauty Dishonoured, about Jane Shore, and Samuel Daniel's Complaint of Rosamond, women are assumed to be especially susceptible to sin. As they are physically weak, so they are morally weak and likely to fall, so much so that Giles Fletcher scorned his fellow poets who thought it worthwhile 'To write of women and of women's falls,/Who are too light for to be fortune's balls.'. . Women in these poems do not have dilemmas like Lucrece's: they follow their desires, they sin, and they are punished.... These women [Rosamond, Jane Shore, and Elstred] cannot discuss and debate moral issues because they have no choices, no power over themselves or others. Shakespeare's Lucrece, on the other hand, is complex and powerful. She confronts a moral dilemma, exploring the meaning of chastity and its connection to personal honor and integrity. She takes responsibility for her fallen state and resolves her dilemma through an act that restores both personal and social harmony. Within the terms set by Shakespeare's poem, Lucrece's suicide is a positive, constructive, and self-creative act. (210-11)

Lucrece's story is plagued by doubleness, but the most dangerous irreconcilability is between rape and pleasure. It is tempting, no doubt, to infuse Shakespeare's otherwise listless work with the humor and parody of his successors-whose jocundity was often derived from the belief that Lucrece was not raped at all, but rather enjoyed the sexual act with a former paramour. (Some have gone as far to say that her muffled scream was simply an orgasm.) It is tempting. Rape, being hidden within the body-especially within the mysterious and "invisible" female genitalia—is an undetectable crime. Lucrece addresses it as an "unseen shame, invisible disgrace!" (827). Perhaps, then, Shakespeare focuses upon Lucrece's body (and on the visual) in an attempt to exculpate her. By dissecting her body, by fragmenting the whole - a splitting apart of parts-he can expose the otherwise concealed act. Though Shakespeare gives her voice-too much at times-according to critics such as Jocelyn Catty, voice will remain ineffectual since rape generally only truly generates a swansong type of utterance, i.e., only generates 
voice when death encroaches: "And now this pale swan in her wat'ry nest / Begins the sad dirge of her certain ending" ([emphasis added] 1611-612).

A similar shift from voice to body, from language to gesture, is apparent in Shakespeare's play, Titus Andronicus (1593-4), written only a few months before The Rape of Lucrece. Jonathan Bate indicates that:

where Lucrece sometimes seems to disappear in the "helpless smoke of words' of her poetic complaints (Luc 1027), Lavinia is a 'speechless complainer' but a bodily presence. Her body is at the core of the action, as images of the pierced and wounded body are central to the play's language. (Shakespeare, Titus 36)

Like in Titus, the unreliability of words in the poem moves Lucrece (and Shakespeare) forward to the only other outlet available: the visual. Ironically-like Lucrece's use of Tarquin's dagger to cleanse herself of his sin-the initial exposure (the rape) necessitates other types of exposures, including an anatomization of her body. I will, therefore, explore the body—in metaphorical parts, dismembered, or apotheosized/de-corporealized-in an attempt to excavate meaning in The Rape of Lucrece. In the first section, I will explore the breast, the eyes, and the tongue to link Lucrece with other commanding mythological figures. These so-called "wild women" include the Amazons, Medusa, Arachne and Philomela. In the second section, the hand, the eyes, the knee, and the stomach will be investigated, all of which either link Lucrece, or sever Tarquin, from the Divine. In the final section, Classical Mythology and Protestantism conflate in the disembodied figure of Helen of Troy. 


\section{BODY \& MYTHOLOGY}

The Rape of Lucrece is a typically Renaissance work in that it is strewn with body parts. Though it is Lucrece's members which are showcased, the text also evaluates the body through other means: Tarquin's appendages, overt corporeal metaphors, and the array of segmented parts on the tapestry. In their introductory chapter to The Body in Parts, entitled "Individual Parts," David Hillman and Carla Mazzio assert that:

The proliferation of social and symbolic practices of 'piecing out' the body in the early modern period (be it by punitive dismemberment, pictorial isolation, poetic emblazoning, mythic spargamos, satirical biting, scientific categorizing, or medical anatomizing) has generated a significant body of recent criticism about the logic of fragmentation (Introduction xi).

They argue, however, that fragmentation does not necessarily connote objectification. On the contrary, the isolated body part, in the texts of the period, is a subject: "both in the sense that it is increasingly marked and elaborated upon in a range of visual and textual spaces, and in the sense that it is frequently imagined to take on attributes of agency and subjectivity" (Body xii).

Those body parts act as "vehicles of culture and symbolization, as organs with eerily individuated agencies, as objects of libidinal cathexes, as instruments of sentient experience, as imagined loci of self-knowledge and self-alienation. What is imagined here is indeed, as Pascal vividly put it, 'a body full of thinking members"' (xii). Hillman and Mazzio maintain, furthermore, that because "corporeal parts have individuated functions, locations, and differentiated relations to the body as a whole, they can become concentrated sites where meaning is invested and often apparently 
stabilized" (Body xii). In other words, meaning in the Renaissance, and in The Rape of Lucrece, is found in the piece-meal body.

\section{The Amazonian Breast}

The entire scene in The Rape of Lucrece in which Tarquin approaches Lucrece's bedchamber can effortlessly be read as sexual references which foreshadow the act of rape: the "little vents and crannies of the place" (310) indicate the orifices of the body (the house); the "torch" (311) ignited and extinguished may refer to the phallus, and the "glove" (317) to the vagina. When "the wind wars with his torch to make him stay, / And blows the smoke of it into his face" (311-12), it extinguishes "his conduct" which the footnote defines as "guide" (313). The torch more than lights his way, it is his guide, it is what leads him on his path. If the phallic torch is extinguished, i.e., his erection/desire has been quelled, then nothing foments him. It is his "hot heart" which "puffs forth another wind that fires the torch" (315). Taken biologically, it is his heart which pumps the blood back into his penis, "firing up" the torch. According to Debora Shuger, cited in Scott Manning Stevens's chapter "Sacred Heart and Secular Brain," "“Erotic desire [in the Renaissance] is physical, but primarily affects the upper body; it . . dwells in the heart"" (Body 277). In following this train of thought, the line-_"And being lighted, by the light he spies / Lucretia's glove, wherein her needle sticks",2 ([emphasis added] 316-17)-is doubly suggestive: while the torch has been lit, Tarquin himself has also become enflamed/aroused. Tarquin's "hot heart" persuades him to "make his stand" (a pun on

\footnotetext{
${ }^{2}$ If the glove symbolizes the vagina, then perhaps the needle symbolizes the clitoris-which "sticks" Tarquin in the sense that, as the locus of sexual pleasure, it embodies the threat of excessive female power.
} 
erection) on what he deems "the heart of all her land" ([emphasis added] 438-39)—her breasts.

When Lucrece's breasts are described as “ivory globes circled with blue, / A pair of maiden worlds unconquered" (407-8) the martial metaphor of Lucrece as a land about to be conquered by Tarquin, the "foul usurper" (412) is clear. ${ }^{3}$ However, the breast "embodies" more than a political territory. Kathryn Schwarz claims that it is the breast, more than any other female body part, that serves as "a metonym for the feminine" (Mazzio 149): "Again and again in the medical, social, and more explicitly fictional narratives of the English Renaissance, representations of the female breast reify the logic that puts women in their place. .... Functionally defined, the female body imposes a causality of acts as women play the social parts to which their body parts confine them" (Mazzio 147-48). The breast symbolizes a woman's confined space-a limited sphere enacted by patriarchal power. She is a mother, a daughter, a wife-helpless both at the hands of a man, and at the mercy of patriarchy. She is, in a sense, merely a breast.

Yet, a single exposed breast—Lucrece sleeps with one breast exposed: "His hand ... march'd on to make his stand / on her bare breast" ([emphasis added] 437-39)—often indicates the diametrical opposite through its connection with the monomastic Amazons. Schwarz claims that "if the breast is used to represent categories-iconographic, aesthetic, erotic, maternal, domestic —and to articulate the logic through which women are confined to certain spaces, then the willed absence of the breast, like the fear of excess that surrounds maternity and female desire, challenges that spatial logic" (Mazzio 
157). Amazons, according to Schwarz, "disrupt patriarchal logic" (Mazzio 157-58), and Lucrece, it should be remembered, committed suicide by stabbing her breast. Lucrece stabs the very symbol of female power and difference with the hidden, phallic knife-the same conventionally phallic weapon wielded by the Amazons (Mazzio 163):

Even here she sheathed in her harmless breast

A harmful knife, that thence her soul unsheathed;

That blow did bail it from the deep unrest

Of that polluted prison where it breathed. $(1723-726)^{4}$

Does Shakespeare's choice of location for penetration symbolize Lucrece's denunciation of her assigned roles? Most versions of the myth make the breast the explicit site of penetration. However, it should be said that Shakespeare's account of the tale is manifested, not only through what material he chooses to omit or modify from his sources, but through what he chooses to embrace unaltered.

It is consequential that the breast is chosen as the spot where the knife enters considering the relationship between the breast and voice. Even though the notion may have been obsolete by the 1620 's, there existed a notion that "the voice comes from the breast, and that to have a good breast is thus to have a good voice" (Mazzio 165).

Shakespeare may be playing upon this notion, since it is the veins in her breasts that alert her to the forthcoming danger; they are the ones to "tell her she is dreadfully beset, / And fright her with confusion of their cries" ([emphasis added] 444-45). Lucrece speaks incessantly throughout the poem, until, that is, she realizes just how ineffectual words are

\footnotetext{
${ }^{3}$ This is consequential considering the cartography of the period which often superimposed the Virgin Queen Elizabeth's image over the map of England positing both her and England as powerful against "penetration."

${ }^{4}$ Vagina, it should be noted, is Latin, for sheath.
} 
for a woman in her position, in her society. By stabbing her breast she surrenders herself to action.

Since the breast is often what is used to distinguish the sexes, its physical difference carries onto social differences; hence theories involving the breasts often furthered the notion that women are merely vessels, underscored by their generative purposes, and therefore should be kept subservient:

Again and again in the medical, social, and more explicitly fictional narratives of the English Renaissance, representations of the female breast reify the logic that puts women in their place .... Accounts of generation that define woman as matter, man as spirit, find material proof in the production of milk, in the image of the woman acting as a vessel in the most literal possible sense. (Mazzio 147)

Amazons are believed, by numerous critics, to avoid any maternal tasks. Tyrell, quoted in Schwarz's chapter, asks: “'Why, in analyzing the name ['Amazon'], did singlebreastedness seem appropriate? One reason is movement-not only movement as freedom to hurl the javelin but movement as freedom from nursing. . . . As much as possible, Amazons are released from maternal attachments"' (Mazzio 159). But, what of Lucrece and the issue of pregnancy?

Lucrece is not only aware but terrified that she may be with child. She refers to pregnancy in a number of instances: "this bastard graff shall never come to growth: / He [Tarquin] shall not boast who did thy [Collantine] stock pollute, / That thou art doting father of his fruit" (1062-64); "Leaving his spoil perplex'd in greater pain: / She bears the load of lust he left behind" (733-34); "This forced league doth force a further strife; / This momentary joy breeds months of pain" (689-90). This fear is apparently a result of the phantasmagoric Galenic belief that conception equals consent. By this thwarted logic, if 
a woman becomes impregnated then she enjoyed the sexual act-no matter how violent—and if she enjoyed it then it was not against her will. Baines designates medicine as one source of this tenet:

most medical men of the Renaissance, like their medieval predecessors, sided with Galen ... [who believed that] the female, as well as the male, produces semen and that conception results from the meeting through coitus of the two forms of semen ... the medical consensus is that conception does not occur without the delectatio of the woman as well as the man. (79)

Baines indicates, however, that not only the medical, but the Judeo-Christian religious establishments, antagonized women by their constant attempts to rationalize woman's stereotypical carnality:

The hierarchical association [set up in Genesis], man is to soul as woman is to body, aligns the man with rational will and woman with carnal pleasure. It is then a very short step to assume that the carnal pleasure that defines woman, that makes her always ready for coitus, easily overrides the will to resist, and thus to believe that sexual intercourse is always, in some sense, consensual for the woman. (81-82)

During Tarquin's attempts to gain Lucrece's acquiescence, he threatens that the dishonor would affect not only her or her husband, but her children:

'Thy issue blurr'd with nameless bastardy.

And thou, the author of their obloquy,

'Then for thy husband and thy children's sake,

Tender my suit; bequeth not to their lot

The shame that from them no device can take,

The blemish that will never be forgot.' (519-36)

Linda Woodbridge elucidates the political context of illegitimacy in the Renaissance. According to her, bastardy reflects England's own position during Elizabethan rule: “'All over Catholic Europe, as well as in Ireland, Elizabeth was regarded as illegitimate, and unlikely to remain for long on the throne she had wrongfully ascended"' (340). 
Tarquin plays upon one of Lucrece's greatest fears—-the slander involved in bearing an illegitimate child, which itself parallels a second rape: "Such ear-poisoning was a penetration like rape: the ear seemed vaginal; the Virgin Mary supposedly conceived through the ear" (Woodbridge 335). This, of course, is a common Shakespearean image. This notion of bastardy in The Rape of Lucrece, however, remains somewhat anomalous. If Lucrece was already a mother, then her children would be suspect since she would have gained a posthumous reputation as promiscuous-being slain in her bed with a servant. However, since no mention was made of any existing children, then her murder by Tarquin would also have been the death of the unborn child. How then could her children be tainted by the brand of illegitimacy? This is not necessarily Shakespeare's idiosyncrasy, but Tarquin's. Through the heat of lust he simultaneously expresses both his desperation and his conniving manipulation of society's attitude towards the victims of rape.

Hence, killing herself is not only her way of exhibiting grief, but of avoiding slander. Lucrece recognizes silence as an impropriety, at least according to the courts, which is part of the reason she swears that her tongue "shall utter all" (1076). If no mention were made of the ravishment then the child would be assumed to be Collantine's. However, if she did reveal the transgression, as the courts demanded, and was found to be with child, then it would have been assumed she willed it. The ensuing suicide allows her to identify the perpetrator, because in death she takes the unborn with her and thereby avoids further opprobrium. Suicide must accompany her show, and carefully construed speech, since gestation would have symbolized, for both the State and the Church, her joyance during the rape. 
Lucrece's "anticlimactic" (literally) performance serves as a homily for the ravished woman who wants to "cleanse" her "stain." Suicide is condemned in the Christian belief, but was seen as virtuous in the Roman world. According to $17^{\text {th }}$ century laws, on the other hand, a rape victim must both speak out against the perpetrator and show the injury to reputable men. Lucrece, as a conglomerated image of both worlds, then, does all three. For Elizabethan readers, however, she would still not have been exculpated because of the ambiguities in the text regarding impregnation. It seems that the possibility of a "load of lust" left by Tarquin, i.e., pregnancy, was indeed an indelible brand of shame, if not for Lucrece's audience, then at least for Shakespeare's.

Does the stabbing symbolize her Amazon-like severing, not only of her breast, but symbolically of her maternal role? Even if not, Shakespeare's depiction of Lucrece as bare-breasted, and his indications of her possible gestation, imbue her with a sense of power even within the confines of patriarchy. As Schwarz has elucidated:

Stories of children who gain martial valor through being nursed by Spartan women recur throughout ... texts, recalling Volumnia's claim to Coriolanus: 'Thy valiantness was mine, thou suck'st it from me.' In such narratives the beast has more power than the womb or even the seed, excluding men from the child's formation; whether exposed for the sake of nursing or of fashion, the breast threatens always to signify an excess of female control. (Mazzio 153)

The power inherent in the exposed female breast remains, then, in spite of rape.

\section{Medusa's Stiff Gaze}

Like hundred-eyed Argos, there are eyes literally everywhere in The Rape of Lucrece. However, before venturing into this complicated theoretical labyrinth, it is crucial to understand the two opposing schools of thought in regard to the eye's 
ideological power. In the Galenic theory, "the eye is both sovereign and implicitly male: it engenders the visible world by its projection of spiritual substance, the 'pneuma' that flows out through the hollow optic nerve, exciting the surrounding air and translating it into a receptive body" (Mazzio 198). The eye is, in this case, phallic, attested to by its emission of pneuma - which literally means "breath" and which was believed to be the principle component of sperm (Laqueur 41). "The rival theory of vision in the early history of European optics," according to Lobanov-Rostovsky, "envisions the eye as a vulnerable orifice, a passive receiver of light. ... Aristotle's eye is a womb of light, conceiving the world within itself in passive acceptance of its forms" ([emphasis added] Mazzio 199). The theory of the gaze-and its erotic, destructive power-develops out of the gendering of the eye.

According to Lobanov-Rostovsky, "Consciousness, manifested as an act of selfconception-idea (from idein, 'to see')—begins in the act of visual perception. Eye become 'I,' the self perched at the edge of the body" (Mazzio 202). Inherent in that theory is the need to limit the eye's power because "the analogy exposes the self to the many threats implicit in the eye's engagement with the world, its vulnerability to disease, deception, and the objectifying power of another's gaze" (Mazzio 202). In rape narratives, the voyeuristic, intruding male gaze often parallels the act of rape itself. In Lucrece, Tarquin is all eyes.

When the speaker states that "this heraldry in Lucrece' face was seen, / Argu'd by beauty's red and virtue's white; / Of either's colour was the other queen" (64-66), it is Tarquin who sees the theatrical color war with his "traitor eye" (71-73). When he approaches Lucrece's bedchamber, he uses a "waxen torch" to serve as "lodestar to his 
lustful eye" (178-79). The scene where Tarquin encircles Lucrece's curtained bed underscores the voyeuristic nature of his hunt: "The curtains being close, about he walks, / Rolling his greedy eyeballs in his head" (367-68). When gazing at every part of Lucrece's sleeping body—which only aggrandizes his power-the narrator states that "in his will [lust] his wilful eye he tired" (417). Furthermore, it is his eye "which gives the watch-word to his hand full soon, / To draw the cloud [curtain] that hides the silver moon" (370-71). Lucrece will have to sell everything dear to her to his sight, because of his unholy sight: "holy-thoughted Lucrece to their [his eyes'] sight / Must sell her joy, her life, her world's delight" (383-85). Tarquin claims that though he considered the anguish that will ensue, will is all eyes and no ears: "will is deaf, and hears no heedful friends; / Only he hath an eye to gaze on beauty, / And dotes on what he looks, 'gainst law or duty" (495-97). In fact, his pre-rape mantra can be summarized in one line: "my heart shall never countermand mine eye" (276).

However, in the erotic poetry of the period, the male objectifying gaze is often merely a retaliatory weapon used against the power of the woman's transcendent beauty. Lobanov-Rostovsky asserts that "the urge to tame the female gaze common to Petrarchan love imagery derives from the convention that the male lover's eye is a vulnerable orifice, wounded by beauty. . . Beauty is a weapon that solicits the eye, then strikes through it to pierce the soul" (Mazzio 202). The scene, in Shakespeare's Richard III, in which Richard woos Anne is an example. When Anne exclaims, "Out of my sight! Thou dost infect mine eyes," Richard replies, "Thine eyes, sweet lady, have infected mine" (1.2.151-52). Likewise, while the objectifying gaze, in The Rape of Lucrece, may seem to belong to Tarquin, he is in actuality, powerless before Lucrece's beauty-which has the 
power, simultaneously to elicit his gaze and to objectify/effeminize him. Daniel's

Rosamond declares that not even the king could defend himself against her eyes: "No Armour might be fouond that could defend, / Tranfpearcing raies of criftall poynted eyes" (176-77). Shakespeare's description of the sleeping Lucrece is similar, for she, too, is described in terms relative to the sun:

Look as the fair and fiery-pointed sun

Rushing from forth a cloud, bereaves our sight:

Even so, the curtain drawn, his eyes begun

To wink, being blinded with a greater light. (372-75)

Even the portentous word "pointed"-suggestive of the dagger-is used in both cases. Tarquin's argument, his line of defense, parallels Rosamond's-that beauty ravishes the senses: "the fault if thine, / For those thine eyes betray thee unto mine. / . . . Thy beauty hath ensnar'd thee to this night" (Shakespeare 482-85). While Rosamond argues that all is "vanquifht by a glance" (171), Tarquin says that "all orators are dumb when beauty pleadeth" (268).

Tarquin blames, not himself, but Lucrece's beauty for the transgression: "the fault is thine, / For those thine eyes betray thee unto mine" (482-83). Unable to vocally describe Lucrece's beauty, he is enchanted "In silent wonder of still-gazing eyes" (84). It is telling, then, that as soon as Tarquin finally does see Lucrece in bed, he can no longer see-he is blinded: "his eyes begun / To wink, being blinded with a greater light" (37475). That greater light is, metaphorically, Lucrece's beauty. And though Tarquin attempts to maintain his subjectivity by becoming the eye which actively sees, and not one which is seen, this safe place is only in his thoughts:

Within his thought her heavenly image sits, And in the self-same seat sits Collantine. 
That eye which looks on her confounds his wits;

That eye which him beholds, as more divine,

Unto a view so false will not incline. ([emphasis added] 288-92)

Moreover, he apparently desires to be covered by night's cloak in order not to be seen, and hence, is adroitly likened to a serpent who is powerless if seen: "treason works ere traitors be espied. / Who sees the lurking serpent steps aside" ([emphasis added] 361-62).

This reference to a serpent is important. Like Aaron, of Shakespeare's Titus Andronicus, who refers to his own eyes as "deadly-standing" (2.2.32), the narrator in Lucrece comments that Tarquin's “cockatrice' dead-killing eye" (540) rouses him up. Pooler, quoted in the footnote, defines a cockatrice as "a mythical serpent, more often called a basilisk": "Topsel's History of Serpents (1608) says of its deadly effect on man: 'with his sight he killeth him, because the beams of the Cockatrices eyes do corrupt the visible spirit of a man, which visible spirit corrupted, all the other spirits coming from the brain and life of the heart, are thereby corrupted, and so the man dyeth"' (92-3). Though this seems to further aggrandize Tarquin's power-he is the cockatrice whose gaze kills-power actually still rests with the woman. Though Tarquin's eyes are active subjects, he, in a sense, is only reacting to the belittling power of her eyes. Nancy Vickers elucidates how the violating male gaze, Tarquin's in this case, is in some sense retaliatory:

the violence implicit in the Petrarchan poet's gaze represents a reaction to the objectifying power of the beloved's beauty. ... The crucial element in this impulse to tame the female gaze is the objectifying power of desire. The poet imagines the woman's eye as a basilisk, fatal in its power to penetrate the male lover's body and poison his soul. (Mazzio 205).

Shakespeare's metaphor-relating Tarquin to the cockatrice because of his perilous gaze-is counter-productive since, according to Vickers, it is the woman who is 
traditionally deemed the basilisk. This may have something to do with its relation to Medusa. The Basilisk, according to Sergio Lobanov-Rostovsky, in his chapter entitled "Taming the Basilisk," is associated with the threat of female desire because of a common myth of its origin:

Lucan notes that the basilisk was born from Medusa's blood, inheriting her power to turn men to stone. In these terms, the basilisk's lineage invokes the connection between an excess of male desire (Medusa's rape by Poseidon, the stiffening of male flesh) and the fear of an objectifying female gaze. The metaphor, like Perseus's shield, protects the power of the male eye by displacing it onto the woman. (Mazzio 205-6)

Medusa's gaze turns men to stone-the stiffening of flesh apparently denoting erection.

Medusa's monstrosity was a punishment for licentiousness-though many, like LobanovRostovsky, claim she was actually raped. In essence, her punishment-men cannot look at her without being turned to stone-parallels her sin. As a beautiful woman, her gaze was just as dangerous, and her ability to "stiffen" men just as apparent. She was punished because of the power of her beauty. Freud, according to Hilllman and Mazzio, "links the Medusa to anxieties about castration ... [where] 'Medusa's head takes the place of a representation of the female genitals"” (Mazzio xvi).

Lucrece's face is a readable text. She believes that others can see her shame:

They think not but that every eye can see

The same disgrace which they themselves behold;

And therefore would they still in darkness be,

To have their unseen sin remain untold. (750-53)

Not only does she want her sin to remain unseen and untold, she does not want to be able to see others any longer and "bids her eyes hereafter still be blind" (758), for she fears to see a reflection of her shame on their face. Women, Lucrece believes, cannot hide their inner shame: "Though men can cover them with bold stern looks, / Poor women's faces 
are their own faults' books" (1252-253). Everything can be seen on a woman's face.

However, Tarquin knows that his "lustful eye" will also lead to his own "eyesore":

"though I die the scandal will survive / And be an eye-sore in my golden coat" (204-

5).Tarquin's golden coat/shield and Lucrece's face are of utmost importance, especially in relation to Medusa.

In Nancy J. Vickers's article “"This Heraldry in Lucrece' Face,"” she defines a blazon as "first, a codified heraldic description of a shield, and, second, a codified poetic description of an object praised or blamed by a rhetorician-poet. . . . The metaphor, 'woman's face (or body) is a shield,' literalizes this double extension of the term 'blazon'-text describing a shield and text describing a body" (175-76). She argues that "the body Collantine praised . . . is a partial body; a face; its distinctive features are the colors of its flesh and the brightness of its eyes. Color and brightness define Lucrece.... Lucrece's face becomes an animated shield colored in alternating red and white" (17778). Vickers argues that:

Medusa figures in two contexts as a face on a shield: first, Perseus uses a shield to reflect her image and thus avoid looking at her directly, her mediated image permiting [sic] her decapitation; and second, when the battles of Perseus are done, he gives the head of Medusa to Athena who bears it on her aegis, an aegis copied by later warriors. (182)

Lucrece's face - in which red and white do battle-and Medusa's face-transposed unto a shield-are so powerful, they have been incorporated into the masculine realm of war. Indeed, the face of a beautiful woman is the ultimate weapon. Vickers cites John Freccero: "'Whatever the horror the Medusa represents to the male imagination . . . it is in some sense a female horror. In mythology, the Medusa is said to be powerless against 
women, for it was her feminine beauty that constituted the mortal threat to her admirers' (1972:7)" (182):

The association with the image of the Medusa, a beautiful woman punished with monstrousness for a forbidden sexual encounter-some traditions define it as a rape-introduces a deep ambivalence into the 'heraldry in Lucrece' face.' The monstrous becomes the other side of the beautiful; the obsessively spoken part - the face-the other side of the obsessively unspoken but violated part-the genitalia (Ferenczi 1927:360; and Freud 1963:105-106 and 174). (182)

However, the theory behind the Medusa is vital not only in relation to Lucrece's

face, but to her eyes. A cockatrice seems to be the male equivalent of the medusa. While a medusa kills when others look at her, a cockatrice kills by looking at others. This falls in line with the theories behind the gaze. A woman inflicts pain upon a man when she is seen — her beauty is crippling—and a man inflicts pain upon a woman when he looks at her-his gaze, characteristic of men, is penetrating. However, the cockatrice, as Vickers has articulated is a symbol, like Medusa, of female, not male, power. According to Lobanov-Rostovsky:

it is not female desire that the image of the basilisk invokes but a male fear of the woman's gaze, which threatens to solicit or destroy male desire. 'Cockatrice' was Elizabethan slang for a prostitute. While the analogy may originate in an aggressive eye that solicits male desire, the prostitute's trade is based upon her status as not one who looks but who is looked at: prostitution, by its Latin etymology, means to set or place (statuere) in public (pro), available to all eyes" (Mazzio 206).

\section{Philomela's Phantom Limb: The Tongue}

Ian Donaldson's The Rapes of Lucretia: A Myth and its Transformations includes the 1674 work of an anonymous German engraver depicting the rape of Lucrece. The engraving "shows in the inner scene at the left a naked Lucretia about to be raped by 
Tarquin, and, on the right, a clothed Lucretia killing herself in the presence of the men. At the open window hangs a parrot, emblem of talkativeness: the story is soon to be spread to the world beyond" (Donaldson 17). The myth of Lucrece, in all forms of representation, is always, in some way, associated with the issue of voice.

Daniel's Rosamond, for example, was King Henry II's mistress, who was kept confined until discovered by the queen and forced to take her own life. Her ghost seeks a poet to tell her tale in the hopes that he can procure sympathy from the living, and thereby gain her entrance into heaven. Though Shakespeare chose a different story and heroine then Daniel, both works are written in the seven-line rhyme royal, or Troilus stanza, both are adaptations of the popular complaint poems of the $1590 \mathrm{~s}$, and at the center of both is a woman who seeks exoneration along with an audience.

In Daniel's poem, Rosamond's ghost comes from "the horror of infernall deepes" (1) in the hopes of persuading the poet to take up her case. In Shakespeare's version, Lucrece says that "deep torture may be call'd a hell, / When more is felt than one hath power to tell" (1287-288). So, Rosamond may metaphorically be in hell because she is voiceless. Female utterance is essential to myths of female power and the fact that Rosamond must rely upon someone else to tell her story is already proof of her feebleness. She has no choice but to rely upon the poet, instead of herself, to persuade his readers to empathize with her. For, if he can bring them to sigh for her, then she will be able to pass into the Elysian fields from which she is now denied access:

... my foule is now denied, Her tranfport to the fweet Eligian reft,

Caron denies me waftage with the reft.

And faies my foule can neuer paffe the Riuer, 
Till Louers fighs on earth fhall it deliuer. (8-14).

Language and voice are central also to Livy's version: Arruns's and Titus's misinterpretation of the oracle's words lead to their downfall; Tarquin tells Lucretia that he is armed and says "if you utter a word, I will kill you" (98); during the princes' rivalry at camp Collantinus cries out, “'Stop! What need is there of words, when in a few hours we can prove beyond doubt the incomparable superiority of my Lucretia?" (98). However, Livy's most relevant lesson is that language is not only powerful, language is power. Brutus's words-especially impressive since he was believed to be dim-wittedwon over the people and led them to revolt: "The effect of his words was immediate: the populace took fire, and were brought to demand the abrogation of the king's authority and the exile of himself and his family" (101). The figurative mask he wore was one of silence; throwing off that mask meant reclaiming the power of words: "There, publicly throwing off the mask under which he had hitherto concealed his real character and feelings, he made a speech painting in vivid colors the brutal and unbridled lust of Sextus Tarquinius, the hideous rape of the innocent Lucretia and her pitiful death ..." (100). Furthermore, Lucrece had already become a "story"-her tragedy a subject for oration: “. . the horrible story of Lucretia had had hardly less effect in Rome than in Collatia" (100). And, as feminist critics have argued, she had become a means for menparticularly Brutus-to achieve power among men. Because she is not the principal character in Livy's version, she generates voice in others, but is not given one herself. Ovid's Fasti also deals with the issue of female utterance. The fact that Tarquin is taken with Lucrece's words is an entirely Ovidian construction, and is found neither in Livy nor later in Shakespeare. But again, those words-the only ones given to Lucrece at 
that meeting - are words of adoration for her husband and hatred for a war which keeps him from her. Furthermore, when Tarquin comes to her chamber he states, "'Lucretia, / I've got my sword. It's Tarquin speaking'" ([emphasis added] 795-96). He persists "with prayers and bribes and threats" (805). She, on the other hand, loses the ability to voice herself:

... She'd lost her voice, the strength to speak was gone and with it all composure.

What to do? Resist? A woman who resists will be overpowered. Cry out? The sword in his hand prevented that. (797-802)

Unlike in Shakespeare where Lucrece tells all, in Ovid, "She told what she could, but not the last part" (827). She does not, as in Livy and Shakespeare, ask them to revenge the wrong - though she does seem, after death, "to shake her head in assent" (846) when Brutus swears that "Tarquin and his line will be banished to pay for this" (843). In Ovid, then, she is truly a tragic, helpless figure and lacks much of the power attributed her in the other versions.

Furthermore, one of the most enigmatic parts of Ovid's version is the final stanza in which the narrator speaks directly to Procne, Philomela's sister:

Am I wrong, or has spring's harbinger, the swallow, come without care for the return of winter weather?

But, Procne, you'll often complain that you came too soon, and your husband Tereus will be pleased that you're cold. (853-56)

There is no transition from the story of Lucretia to that of Procne and Philomela save for the white space between stanzas. The reader is left to forge the anomalous connection. Not so in Shakespeare's Lucrece. 
In Shakespeare, voice is a complicated issue, especially since the entire work is composed of conversation-dialogue and self-reflections-in which action's only place, ostensibly, is to instigate the discussions. Lucrece, being the protagonist does talk, but her incessant tongue suggests that she suffers from logorrhea. A first-time reader of the poem will need to struggle through, and will undoubtedly complain about, the excessive chatter-talk that seems to distract from, or disrupt, the action. Indeed, Katharine Eisaman Maus, in her article "Taking Tropes Seriously: Language and Violence in Shakespeare's Rape of Lucrece" claims that:

The Rape of Lucrece helped establish Shakespeare's seriousness as a poet, a suggestion borne out by the popularity of the poem in its own time and the enthusiastic praise it received from many of Shakespeare's contemporaries. The Rape of Lucrece has fared less well at the hands of modern critics, however, who persistently object to its elaborate rhetoric" (66).

According to Maus, Richard Wilbur, Douglas Bush, Ian Donaldson, J.W. Lever, and Coppelia Kahn all believe that "the rhetoric of The Rape of Lucrece conceals, confuses, overwhelms" (66). However, because "the poem proper concentrates not upon action but upon what happens in the interstices between the 'important' moments" (67), an investigation into voice, no matter how discouraging, is essential.

On one hand, the act of rape silences voice. When Lucrece speaks Tarquin silences her, and when she cries out he silences her:

The wolf hath seiz'd his prey, the poor lamb cries, Till with her own white fleece her voice controll'd Entombs her outcry in her lips' sweet fold.

For with the nightly linen that she wears He pens her piteous clamours in her head. (677-81) 
Shakespeare may have been aware of the pseudo-medical texts of the Renaissance which often highlight the affinity between the throat (voice) and the vagina. His phrase "lips' sweet fold," therefore, is doubly suggestive. The act of stuffing her mouth—of silencing her-directly correlates to the rape. This correlation between the violated genitalia and the silenced mouth is obvious in Titus when, for example, Chiron, about to rape Lavinia, says, "I'll stop your mouth" (2.2.184) and literally does so by cutting out her tongue. According to Bate, "the 'mouth' of the pit becomes crucial when we realize that Lavinia is not only being raped but also having her tongue cut out; throughout the play, the action turns on mouths that speak, mouths that abuse and are abused, mouths that devour" (Shakespeare, Titus 9).

The connection between rape and silence is also apparent in Lucrece's apostrophe to Opportunity, in which she says blames opportunity for making "the vestal violate her oath" (883). Presumably, she means that the virgin breaks this oath when she is raped. The punishment for breaking the oath of virginity, according to Elaine Fantham's Women in the Classical World, entails being buried alive and covered so "nothing she utters may be heard" (237). If a vestal virgin engages in sex, then, her punishment involves the theft of her voice. Lucrece seems to blame Opportunity—rape—for that theft.

However, on the other hand, rape also generates voice. In other words, though Tarquin "pens" her piteous clamours, i.e., traps/imprisons Lucrece's voice during the rape, this forces her to "pen" (write) her rape afterwards. Lavinia, of Titus Andronicus, for example, is forced to put the stick - with which she writes the word rape-in her violated mouth. It, in essence, reenacts the rape, but it also gives Lavinia a means of communication, a phantom tongue. Likewise, in Lucrece, Tarquin seems to catalyze 
"voice" in everything that he forcibly encounters-Lucrece, the creaking doors, and the "Night-wand'ring weasels [who] shriek to see him there" (307). In essence it is not Tarquin, but the act of rape itself, since, according to Donaldson, Lucrece's exposed body initiated voice in Brutus, causing him to speak eloquently, surprising all: "Lucretia's body was displayed at Collatia and at the Forum in Rome, where Brutus amazed the Romans with his transformed personality and the power of his oratory" (5). Rape, then, according to Jocelyn Catty, "both necessitates and circumscribes female utterance: legitimises and silences it" (3).

Rape both authors ("pens") and silences ("pens") voice, but the poem presents words alone as ineffectual anyway. All men in the poem are unable to describe Lucrece's insurmountable beauty. Her beauty exceeds their vocal skills. Tarquin believes Collantine to be an unskilled publisher of Lucrece's beauty:

Now thinks he that her husband's shallow tongue,The niggard prodigal that prais'd her so,In that high task hath done her beauty wrong Which far exceeds his barren skill to show. (78-81)

Though there is no evidence that Shakespeare may have relied upon Ovid's Heroides in writing Lucrece, Paris's arguments in his letter to Helen are strikingly similar to Tarquin's. In that letter, Paris says:

... Fame has told all, your beauty is made known to every nation.

No woman of beauty is like you, your reputation is less than the truth and has all but denied your charms. I find more now than I was promised by the goddess and you exceed by far that promise.(152-53) 
Furthermore, the disputation Tarquin holds "“Tween frozen conscience and hot burning will" is "graceless" (246-47) because, according to him, "All orators are dumb when beauty pleadeth" (268). Words are ineffectual in beauty's presence so he says "debating die!" (274). Even though Tarquin accuses Collantine of inadequately describing Lucrece's beauty, he too fails at the task: "Therefore that praise which Collantine doth owe / Enchanted Tarquin answers with surmise, / In silent wonder of still-gazing eyes" ([emphasis added] 82-84). Tarquin cannot rely upon words, so he becomes enchanted into silence, he has become all eyes, and those eyes are insatiable:

... nothing in him seem'd inordinate, Save sometime too much wonder of his eye, Which having all, all could not satisfy;

But poorly rich, so wanteth in his store

That cloy'd with much, he pineth still for more. (94-98)

Tarquin cannot at first tell Lucrece why he has come to her bedchamber, and succumbs to a laughably-pathetic pantomime. When she asks why he has attacked her, "First like a trumpet doth his tongue begin / To sound a parley to his heartless foe" (47071), but then "by dumb demeanor seeks to show" (474). As the footnote indicates, the dumb demeanor hardly coincides with the parley (90). Perhaps, initially he attempts to vocalize his reasons, but being unable, he must depend upon silent comportment. It is only when she further urges an answer that he replies:

...'The colour in thy face, That even for anger makes the lily pale And the red rose blush at her own disgrace, Shall plead for me and tell my loving tale.

Under that colour am I come to scale Thy never-conquer'd fort: the fault is thine:

For those thine eyes betray thee unto mine.

'Thus I forestall thee, if thou mean to chide: 
Thy beauty hath ensnar'd thee to this night. (477-85)

Beauty, again, is at fault; but even in attempting to discuss her beauty, he is struck dumb.

Even the prototypical talker in the poem, Collantine, is struck dumb. Upon witnessing

Lucrece's suicide, he faints. When he recovers he is unable to speak, except in unintelligible utterances:

The deep vexation of his inward soul Hath serv'd a dumb arrest upon his tongue;

Who, mad that sorrow should his use control

Or keep him from heart-easing words so long, Begins to talk; but through his lips do throng

Weak words, so thick come in his poor heart's aid

That no man could distinguish what he said. (1779-785)

Words, it seems, are impotent, unable even to express his sorrow.

Words alone are also ineffectual for Lucrece:

'O peace,' quote Lucrece, 'if it should be told, The repetition [recital] cannot make it less;

For more it is than I can well express,

And that deep torture may be call'd a hell,

When more is felt than one hath power to tell. (1284-288)

She says that words will not relieve the pain because she does not have the ability to express it in its entirety. Donaldson asserts that "unlike the sorrowing Hecuba in the painting of fallen Troy ('so much grief and not a tongue' [1463]), unlike the raped and tongueless Lavinia in Titus Andronicus, Lucrece talks of her griefs, but her talk seems to get her nowhere" (42). Even when she writes the message to her husband, she goes through numerous drafts before it is completed:

Her maid is gone, and she prepares to write, First hovering o'er the paper with her quill;

Conceit and grief an eager combat fight, What wit sets down is blotted straight with will:

This is too curious-good, this blunt and ill. (1296-1300) 
Her letter, however, is brief and obscure:

... 'Thou worthy lord

Of that unworthy wife that greeteth thee, Health to thy person! next, vouchsafe, t'affordIf ever, love, thy Lucrece thou wilt seeSome present speed to come and visit me.

So I commend me, from our house in grief;

My woes are tedious, though my words are brief'. (1303-309)

She tries to stall Tarquin with her pleas, but her words only serve to postpone the inevitable: "So his unhallowed haste her words delays, / And moody Pluto winks while Orpheus plays" (553). Her words, like Orpheus's enchanting music, may tame the beast, but only momentarily.

Lucrece tries to talk away her grief: "So she deep-drenched in a sea of care, / Holds disputation with each thing she views" (1100-101). And though the narrator says that "sometime her grief is dumb and hath no words, / sometime "tis mad and too much talk affords" (1105-106), the reader cannot identify when she has not found the words. And yet, she still finds no peace. According to Donaldson, Lucrece's disputation is "a state of anxiety, not a process of ratiocination.... Whether she is speechless, whether is garrulous, language is inadequate to express her grief" (42). It is no wonder, then, that she may feel apprehensive about relying solely on words for her self-defense, especially since "Lucretia's summoning of her husband and father and their friends may reveal the outlines of an actual legal situation; this group of men might be seen as constituting the iudicium domesticum or family council which could pass judgement upon Lucretia for her part in the events which have occurred" (Donaldson 24). 
After talking ceaselessly for fifty-odd lines, Lucrece finally says that words are useless to her case:

'Out idle words, servants to shallow fools, Unprofitable sounds, weak arbitrators!

Busy yourself in skill-contending schools, Debate where leisure serves with dull debaters;

To trembling clients be you mediators:

For me, I force not argument a straw. (1016-21)

The only thing left to do, she argues, is to take her life:

'In vain I rail at opportunity, At time, at Tarquin, at uncheerful night;

In vain I cavil with mine infamy, In vain I spurn at my confirm'd despite;

This helpless smoke of words doth me no right:

The remedy indeed to do me good

Is to let forth my foul defiled blood. (1023-29)

Before Lucrece's disclosure of the ravishment to Collantine, Lucretius, Junius Brutus and Publius Valerius-representing the men of Rome-she states that "few words ... shall fit the trespass best"(1613). As with the writing, her words may seem "too" good for a humble woman for whom a "soft slow tongue, [is the] mark of modesty" (1220). Accordingly, her wit is forcibly controlled by her will-her emendations reflect her knowledge of the stereotypes placed upon women in society, i.e., that a modest woman was a silent, or nearly silent, woman. However, in the case of rape that very silence also condemns the victim. So, even though words are ineffectual, talk she must.

According to Barbara Baines, who cites the author of The Lawes Resolutions in her article "Effacing Rape in Early Modern Representations," "a raped woman's silence could signify either that she is 'so little offended with the iniury, or so ashamed to confesse the outrage.' In either case, under the statue of 1382, she will be punished by 
being disinherited" (77). That financial punishment was twinned with an even more menacing possibility-slander. Hence, it is Lucrece who understands, better than the noblemen at the end who "all at once began to say, / Her body's stain her mind untainted clears" (1709-10), that her "case is past the help of law"(1022). When she laments that "this helpless smoke of words doth me no right ..." (1027), she is characterizing womankind's position, according to the laws of the Elizabethan period which vilify the victim. To speak is ignoble, to remain silent is unlawful.

Lucrece, then, does speak, but she couples those words with action. Like Shakespeare-who uses corporeal exposure-Lucrece relies not only on words, but on action-on physical proof. She relies on that which can be seen, not only heard. Unlike Daniel's Rosamond, Lucrece refuses to "fold ... [her] fault in cleanly-coin'd excuses" (1073). She refuses to obscure what has transgressed, instead, she will expose the sin, but she will do so with a flood of tears:

My sable ground of sin I will not paint, To hide the truth of this false night's abuses. My tongue shall utter all, mine eyes like sluices, As from a mountain-spring that feeds a dale, Shall gush pure streams to purge my impure tale. (1073-78)

She also refuses to kill herself until Collantine has not only heard her tale, but seen her blood-_“'Thou Collantine, shalt oversee this will; / How was I overseen that thou shalt see it!" ([emphasis added] 1205-206)—and can promise to revenge her:

'Yet die I will not, till my Collantine Have heard the cause of my untimely death, That he may vow in that sad hour of mine Revenge on him that made me stop my breath. My stained blood to Tarquin I'll bequeath

Which by him tainted shall for him be spent And as his due writ in my testament. (1177-183) 
The narrator says that "her certain sorrow [was] writ uncertainly" (1311). She

wrote of her grief, but not of the actual incident because she did not want Collantine to assume the worst of her before she could prove her innocence through suicide

Her grief, but not her grief's true quality;

She dares not thereof make discovery,

Lest he should hold it her own gross abuse,

Ere she with blood had stain'd her stain'd excuse. (1313-316)

Again, she believes that words are only powerful when coupled with action:

... the life and feeling of her passion

She hoards, to spend when he is by to hear her,

When sighs and groans and tears may grace the fashion

Of her disgrace, the better so to clear her

From that suspicion which the world might bear her:

To shun this blot, she would not blot the letter

With words, till action might become them better. (1317-323)

She argues that "to see sad sights moves more than to hear them told, / For then the eye interprets to the ear" (1324-325). The narrator pits action against words even in reference to the minor role of the messenger:

Such harmless creatures have a true respect

To talk in deeds, while others saucily

Promise more speed, but do it leisurely.

Even so this pattern of the worn-out age

Pawn'd honest looks, but us'd no words to gage. (1347-351)

In essence, the man does not promise, through words, that he will fulfill his role, instead he acts out, with honest looks, the role of a good messenger. In other words, as the footnote indicates, he "gave only honest looks as pledge of obedience" (127).

Donaldson claims, "Longing for the simplicity of action, Shakespeare's characters find themselves entangled in a web of words" (43). Shakespeare, the dramatist, seems to understand the shortcomings of poetry_-“"Tis but a part of sorrow that we hear” 

and his focus on the visual seems to reflect his yearning for the spectacle of the

stage. Laura G. Bromley asserts that emotional language "must give way . . language that serves to communicate meaning and inspire action":

This is what Brutus rightly insists, finding an opportunity for the actions that will lead to the exile of Tarquin. He urges Collantine to replace his watery lamentations with the purposeful words of invocation. He vows to avenge Lucrece, then repeats the vow; then the others also swear to act to avenge her death. ... In Shakespeare's poem it is Brutus who, 'burying in Lucrece' wound his folly's show' (1.1810), sees the way to move from the appearance of grief to the reality of grief expressed, restrained, and ultimately transcended by resolution and then action. (209-10)

It must be remembered that Lucrece is less an exposition of the Roman than the Renaissance mentality-where, in the majority of literature, women were silenced, effaced, and marginalized in the company of men. In the presence of those men, then, as opposed to her excessive complaint when alone, Lucrece was forced to espouse her words with action. The female voice was apparently a threat to phallocentric power, so she constructs a visual display to submit to their own stereotypes of women:

Three times with sighs she gives her sorrow fire, Ere once she can discharge one word of woe. At length address'd to answer his desire, She modestly prepares to let them know. (1604-7)

She sighs to add "fire" to the sorrow, to embellish and authenticate it, but she must do so "modestly." In other words, since voice essentially "belonged" to men, Lucrece relies on that submissive, meek mask of womanhood by staging an elaborate exhibition-she dresses in mourning clothes, sighs, and stabs herself. Like Titus-who, according to Bate, "has written the script for the climax of his play" (Shakespeare, Titus 23)-Lucrece performs her revenge. For both Lucrece and Titus, "the formalization of revenge in performance acts as a substitution for the law, simultaneously revealing the law to be 
itself nothing other than a performance, replete with processions, costumes, symbolic geography, dialogues, epideictic utterances and gestures" (Shakespeare, Titus 26-27).

Indeed, Lucrece's melodrama is in exact accord with the laws of the midthirteenth century, upon which the seventeenth century modeled itself. "The raped woman," according to Bracton, "the primary Renaissance authority on rape," "'must go at once and while the deed is newly done, with hue and cry, to the neighbouring townships and there show the injury done her to men of good repute, the blood and her clothing stained with blood, and her torn garments"” (76). The rape victim must exhibit both cry and her blood-stained body.

Lucrece is notably selective with her words in the final scene, as opposed to her arduous complaint, because though she would like to believe that "not the devour'd, but that which doth devour / Is worthy blame" (1256-57), that is not the case. In the lines that follow she pleads:

\section{... O let it not be hild}

Poor women's faults, that they are so fulfill'd

With men's abuses! those proud lords to blame

Make weak-made women tenants to their shame. (1257-60)

That women are "weak-made" is no doubt misogynistic; however, it is not Lucrece's own opinion-she is the one who dramatically vocalizes the tragedy of the Trojan women, who claws at the painting, who devises the entire finale. She cries out, only when alone, against a patriarchal society which, through law, found a way to berate even the victim. According to Bromley, "she can, in Hamlet's words, 'drown the stage with tears / And cleave the general ear with horrid speech' (II.ii.572-73). Lucrece can achieve harmony of 
feeling, expression and appearance, then, and she will do so when her audience is gathered" (206).

Lucrece curses Tarquin by saying that she hopes women will treat him wildly: "'let mild women to him lose their mildness, / Wilder to him than tigers in their wildness" (979-80). Perhaps, she means, as wildly as Philomela and Procne have treated men. Philomela, according to Jane O. Newman's article "Philomela, Female Violence, and Shakespeare's Lucrece":

belongs to and represents the countertradition of vengeful and violent women associated with Bacchic legend. This tradition is replete with images of different, more direct forms of political agency for women, images that in fact challenge the fundamental organization and distribution of power in the Western, patriarchal state" (305).

The myth of Philomela aids in the investigation of the issue of the tongue in Lucrece. According to Thomas Adam's The Taming of the Tongue (1619), a sermon on the abuses of speech, the tongue is "an unruly 'member,' an 'insubjectible subject"' (qtd. in Mazzio 54). Mazzio asserts that "the tongue figures in a range of early modern discourses as a somatic manifestation of all that resists containment" (Mazzio 54). Furthermore, the tongue which "gives 'vent' to voice and subjectivity" and which "bridges the individual and the collective, is also imagined to be a potentially autonomous and separate part of the self, a member that is always already dismembered" ([emphasis added] Mazzio 55). Philomela, in Ovid's telling, "rails against Tereus immediately and calls down his sword upon her when she threatens to declaim the deed in public. His dismemberment of her is a kind of second rape" (Newman 310). However, though Philomela's tongue is severed, she is successful in telling her tale, and in revenging the deed. This phantom "limb" retains its power. Tongue-less, then, is not 
voiceless. In other words, in regards to Lucrece, just because Lucrece cannot rely solely on words does not mean she cannot voice herself.

Lucrece's voice is likened to Philomela's, who also exists beyond sociallyascribed limits: "By this, lamenting Philomel had ended / The well-tun'd warble of her nightly sorrow" (1079-80). Having been transformed into a nightingale (a common image for the poet), Philomela sings (speaks) when pricked by a thorn: “'Like little frosts that sometime threat the spring, / To add a more rejoicing to the prime, / And give the sneaped birds more cause to sing" (331-33). Lucrece also begins to speak under threat of rape-when she is "at the mercy of his mortal sting" ([emphasis added] 364). She tries to silence the cheerful birds of day as Tarquin had silenced her:

'You mocking birds,' quoth she, 'your tunes entomb

Within your hollow swelling feather'd breasts, And in my hearing be you mute and dumb; My restless discord loves no stops nor rests.

A woeful hostess brooks not merry guests. Relish your nimble notes to pleasing ears'. (1121-126)

(Interestingly enough, birds were thought to have a lecherous character and so were used in Renaissance pharmacopoeia to manipulate body heat [Laqueur 103].) The only song she wishes to hear is Philomela's woeful tune, which she will imitate:

'Come Philomel, that sing'st of ravishment, Make thy sad grove in my dishevel'd hair; As the dank earth weeps at thy languishment, So I at each sad strain will strain a tear And with deep groans the diapason bear;

For burden-wise I'll hum on Tarquin still, While thou on Tereus descants better skill.

'And whiles against a thorn thou bear'st thy part To keep thy sharp woes waking, wretched I

To imitate thee well, against my heart

Will fix a sharp knife to affright mine eye, 
Who if it wink shall thereon fall and die.

These means as frets upon an instrument

Shall tune our heart-strings to true languishment'. (1128-141)

Jane O. Newman, in “"And Let Mild Women to Him Lose Their Mildness':

Philomela, Female Violence, and Shakespeare's The Rape of Lucrece" argues that, though Lucrece chooses to sing like Philomela, "the musical harmony suggested by Lucrece's 'diapason' and the bird's 'descant' . . signals difference, in that the songs are in different registers and in dramatically different musical forms" (309). This musical difference unravels other intrinsic differences. According to Newman,

Had Shakespeare used either Cooper's Dictionarium or an edition of the Fasti similar to the one edited by Marsus, as Baldwin suggests he did, he would have found information about a maenadic Philomela which calls into significant question his (and any other) Lucrece's claim to 'imitate' her 'well' while internalizing the blame for and consequences of rape. (315).

Philomela's myth is replete with images of violent, Bacchic, ritualistic dismemberment. Hence, Newman asserts that an examination into Philomela's myth "would have conjured up the image of a women reacting with violence against those who violated them rather than against themselves, with violence sanctioned, moreover, by its inscription in a ritualistic (Bacchic) frame" (316). Lucrece, Newman argues, substitutes Itys as the blood sacrifice needed to oust a tyrant. She asserts that Shakespeare's "rejection of the tale of Philomela and its Bacchic afterlife in the Renaissance" seems "motivated by the need to remove the possibility of female revenge" (321). Though enthralling, Newman's argument seems to overlook the character of Shakespeare's Renaissance audience; the "wiser sort" for which the poem was composed would have been able to recall hideous images of bloody dismemberment through even the most meager of references to 
Philomela. Shakespeare uses Philomela specifically because of what she is associated with-the power of female utterance, whether through speech, or through other means. Lucrece, unable to rely solely on words, does find another text through which to tell her tale. In the "Argument," in which Shakespeare more closely follows his sources Ovid and Livy, he writes that "in pleasant humour they all posted to Rome, and, intending by their secret and sudden arrival to make trial of that which everyone had before avouched, only Collatinus finds his wife, though it were late in the night, spinning amongst her maids"(65). It was "at that time [that] Sextus Tarquinius, ... [became] inflamed with Lucrece' beauty" (65). Critics have argued that the authorship of the "Argument" is questionable, and it is obvious that it differs from the poem itself in which it was only Collantine's boasting, and not the sight of Lucrece, that inflamed Tarquin. However, her "spinning" or weaving was what differentiated her from the "other ladies [who] were all found dancing and revelling, or in several disports" (65). Sewing or weaving, typified by Odysseus's wife, Penelope, is a sign of chastity. But, it also is also a form of female expression.

Weaving, though considered woman's work, may serve as the socially-defiant type of voice characterized by Arachne. According to Ovid's Metamorphosis (8 A.D.), Arachne "dared / To rival Pallas at the loom, to think / Herself superior in art" (163). In her competition with Athena-a competition which in itself is an act of hubris, and hence, a defiance of social norms-Arachne wove a tapestry depicting the numerous forms the male gods have taken to rape a woman:

Arachne wove the story of Europa, Who was seduced by the image of a bull. 
Asteria captured by the wrestling eagle

Came next, then Leda on her back beneath

The swan; then Jove seen as a satyr,

Piercing at once the lush Antiope

... then Jove as a husband

To innocent Alcmena, a golden shower

To Danae, a tickling flame of fire. (166)

As Ovid tells the story, Pallas Athena, so enraged at the girl's success, slashed her face, but Arachne could not "take such punishment: / She'd rather hang herself than bow her head, / And with a twist of rope around her neck / She swung" (166). Pallas thus made her immortal as a spider, "The tenuous weaver of an ancient craft" (167). Jocelyn Catty, in Writing Rape, Writing Women in Early Modern England: Unbridled Speech, argues that "Arachne condemns the gods' rapes of mortal women ... by weaving, and thus contravenes the usual narration of these tales as love stories" (5).

However, the art of weaving, and the needle which pricks Tarquin's finger (31819) also recalls Philomela. Newman's argues that:

Philomela communicates by means of a non-verbal rhetoric that represents woman's language of gesture (as opposed to Lucrece's almost obsessive compliance with the phallocentric logic of reading and writing), weaving in nimble silence the tapestry (1.576) on which the story of her violation is told. This is the alternative 'text' (from texere, to weave) that she sends to her sister, Procne, Tereus's wife. (310)

Newman seems so determined to posit Lucrece as the antithetical "wild woman" that she overlooks the fact that Lucrece does manipulate alternative forms of voice to gain power-forms that are in direct contrast to the phallocentric acts, as she calls them, of reading and writing. Lucrece is a masterful manipulator of "woman's language of gesture" which becomes vital as a result of the dismemberment, metaphorically or otherwise, of the tongue. Though she initially attempts to use language to her benefit, she 
comes to realize its inefficacy. Hence, she stages an elaborate grand production-she acts, using carefully controlled sighs and moans to embellish her tale. Lucrece is a weaver, perhaps not of the sort of Arachne or Philomela; however, she does create her own text and makes sure to maintain authorship over it. Her text is a hybrid of sounds and sights, akin to the tapestry. In fact, she helps to narrate her own tale by reading (and writing - through interpretation) the tapestry. According to Scott, ekphrasis-the description/narration of a visual artwork in poetry-was believed to be a feminine trope. It is often symbolized by the Siren, "who lures men away from their true course (34), because of a general "mistrust of finery and ornament" which stems, in part, "from a fear of its origins in the feminine unconscious":

To embellish is to do women's work; to declare plainly and straightforwardly is to further the 'manly' cause. This dichotomy derives from a debate between clarity and sophistry deeply embedded in Western thought. It belongs to a long tradition of suspicion toward artistsinaugurated by Plato in The Republic - that allots precedence to clear mimetic representation over descriptive embroidery. (33)

Both Shakespeare and Lucrece rely upon the tapestry as an alternative, explicitly feminine, visual text.

\section{Synecdoche, Ekphrasis and the Tapestry}

While Lucrece waits for Collantine's return she pauses from sighing, weeping, and groaning (1362) in order "to mourn some newer way" (1365). She finds that way in the tapestry depicting the fall of Troy. The tapestry in the poem belongs to the genre of ekphrasis (ek-phrassein: to speak out, tell), which, according to Grant F. Scott, is "specifically designed to describe works of art, to translate the arrested visual image into 
the fluid movement of words" (xi). Ekphrasis is "that teasing moment in Homeric tales when the narrative halts and the poet intervenes to describe a shield or a sword or a tapestry" (xi). According to Scott, one of a plethora of purposes of ekphrasis is to "underwrite identity" (2): "The connection between ekphrasis and genealogy is most effectively borne out in Virgil's description of the shield of Aeneas, on which Aeneas witnesses the dazzling exploits of his descendants" (2). Shakespeare's ekphrasis in The Rape of Lucrece has a similar, though two-fold, purpose. The Roman Lucrece beholds her ancestry via the tapestry depicting the Trojan War; but Shakespeare's audience also sought its foundation in "cloud-kissing Ilion." According to Bate,

When the city of Troy fell, Aeneas escaped and founded Rome. In an effort to sustain the pattern, British writers created the myth of Brutus, who also escaped from Troy and founded Britain, London serving as another new Troy ('Troynovant'): our Troy, our Rome, this England" (Shakespeare, Titus 17).

What is interesting, then, is that both Rome and London were mythically founded on rape, the rape of Helen.

One of Shakespeare's sources for such a digression is Daniel. In Daniel, the casket that Henry presents to Rosamond is "richly wrought; / So rare, that Arte did feeme to ftriue with Nature, / T'expreffe the cunning Worke-mans curious thought" (380-82). Rosamond plays the part of the reader in trying to interpret its meaning- "The myfterie whereof I prying fought" (383)—just as Lucrece will with the tapestry, which also rivals nature: "art gave lifeless life" (1375). Shakespeare's tapestry is not only another way of reinforcing the power of the visual, it further exposes the body.

The tapestry is so well-crafted, it seems to breathe life into the dead, and hence competes with nature, and the natural laws: 
A thousand lamentable objects there, In scorn of nature, art gave lifeless life:

Many a dry drop seem'd a weeping tear, Shed for the slaughter'd husband by the wife;

The red blood reek'd to show the painter's strife, And dying eyes gleam'd forth their ashy lights, Like dying coals burnt out in tedious nights. (1373-379)

Tears, blood and body parts abound. Part of the artistic merit of the tapestry is in its focus on the eyes: the women weep; the dead are characterized by the ashy light of their eyes; "from the towers of Troy there would appear / The very eyes of men through loop-holes thrust, / Gazing upon the Greeks with little lust" ([emphasis added] 1382); "Such sweet observance in this work was had, / That one might see those far-off eyes look sad" ([emphasis added] 1385-386). On the tapestry, character can be read in the way one gazes:

In Ajax and Ulysses, $O$ what art Of physiognomy might one behold!

The face of either cipher'd either's heart; Their face their manners most expressly told. In Ajax's eyes blunt rage and rigour roll'd, But the mild glance that sly Ulysses lent Show'd deep regard and smiling government. (1394-1400)

While Shakespeare's audience observes Lucrece, Lucrece observes the figures on the tapestry, and those figures, in turn, observe themselves. Sight seems to be refracted as if off counter-positioned mirrors.

Hillman and Mazzio claim that "insofar as parts were imagined as dominant vehicles for the articulation of culture, the early modern period could be conceptualized as an age of synecdoche" (Mazzio xiii-xiv). Synecdoche is not only an issue in the art of the tapestry; the tapestry is, in effect, a synecdoche of the poem. It is a microcosmic encapsulation of the images and issues prevalent in the poem at large. Although ekphrasis 
seems like a digression, "one of the major impulses of classical ekphrasis, in fact, is synecdochic: the descriptive inset aspires to stand for, sometimes even stand in for, the larger world of which it is a part"(Scott 2).

For example, just as Lucrece is segmented, by Tarquin (and Shakespeare), into a face, a breast, hair and eyes, so too are the soldiers fragmented into body parts:

For much imaginary work was there,Conceit deceitful, so compact, so kind, That for Achilles' image stood his spear Gripp'd in an armed hand; himself behind Was left unseen, save to the eye of mind:

A hand, a foot, a face, a leg, a head

Stood for the whole to be imagined. $(1422-428)$

Furthermore, while the soldiers seem literally piled on top of one another-"Here one man's hand lean'd on another's head, / His nose being shadowed by his neighbour's ear" (1415-416)—Hecuba, in Lucrece's “text," takes center stage. Like Shakespeare, Lucrece minimizes the role of the martial men in favor of one tragic woman. Hence, Hecuba has been doubly anatomized, by both Lucrece and the painter:

In her the painter had anatomiz'd Time's ruin, beauty's wrack, and grim care's reign; Her cheeks with chops and wrinkles were disguis'd: Of what she was no semblance did remain. Her blue blood chang'd to black in every vein, Wanting the spring that those shrunk pipes had fed, Show'd life imprison'd in a body dead. ([emphasis added] 1450-456)

The Trojan war, is often, in Shakespeare, paired with corporeal images. David Hilllman, in his chapter entitled "Visceral Knowledge" discusses Shakespeare's play Troilus and Cressida. He argues that its main thrust is a turn towards the body, "an insistence on the ineradicable role of corporeality in every human endeavor" (87): 
The play refuses to go along with the (self-)mythologizing tendencies of the overblown, idealizing rhetoric of its own protagonists and a rejection of the disembodied, highly rhetoricized status its heroes had achieved in contemporary England. Both within the play and in the cultural milieu in which it was written, Troilus and Cressida enacts a restoration of language and action to their sources inside the body. This somatization constitutes a powerful countermovement to the genealogies of Tudor and Stuart mythographers who traced the ancestry of the English nation to the foundational legend of Troy. That is, while these mythographers sought a heroic site of origin in the Trojan epic, Shakespeare's 'skeptical satire' seeks the origins of the Trojan legend in the bodies of its heroes. (87)

One particular body part—the face, and its readability as a text—is poignant in regards to Sinon, the greatest of all actors:

In him the painter labour'd with his skill To hide deceit and give the harmless show An humble gait, calm looks, eyes wailing still, A brow unbent that seem'd to welcome woe. (1506-509)

The ensuing lines, which describe Sinon's cheeks,-_"Cheeks neither red nor pale, but mingled so / That blushing red no guilty instance gave, / Nor ashy pale the fear that false hearts have" (1506-512)—hark back to the description of Lucrece's cheeks in which red and white also commingle:

This heraldry in Lucrece' face was seen, Argu'd by beauty's red and virtue's white;

Of either colour was the other queen, Proving the world's minority their right. Yet their ambition makes them still to fight;

The sov'reignty of either being so great, That oft they interchange each other's seat. (64-70)

While on Lucrece's cheeks red symbolizes beauty and white virtue, on Sinon's cheeks, red symbolizes guilt and white fear. Shakespeare seemingly associates Lucrece with a person of base character - as with Helen of Troy—only to adequately rupture any 
similarities. The parallelisms are constructed, only to be razed. Sinon is the mastermind masquerader:

... like a constant and confimed devil, He entertain'd a show so seeming just, And therein so ensconc'd his secret evil, That jealousy itself could not mistrust

False creeping craft and perjury should thrust

Into so bright a day such black-fac'd storms,

Or blot with hell-born sin such saint-like forms. (1513-519)

Sinon's bewitching story, his words, "like wildfire burnt the shining glory / Of rich-built Ilion" '(1524). She looked at his picture deliberately, for she believed the painter had made a mistake in depicting his body since "so fair a form lodg' $\mathrm{d}$ not a mind so ill" (1530). She cannot accept that there is no outward trace of his inner corruption, until she recalls Tarquin:

'It cannot be, quoth she, 'that so much guile,'She would have said,-_can lurk in such a look.' But Tarquin's shape came in her mind the while,

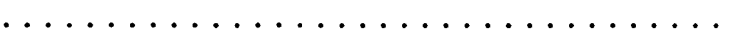

'For even as subtle Sinon here is painted,

So sober sad, so weary and so mild,As if with grief or travail he had fainted,-

To me came Tarquin armed to beguild

With outward honesty, but yet defil'd

With inward vice. As Priam him did cherish, So did I Tarquin,-—so my Troy did perish. (1534-547)

When Lucrece asks Priam why he listened to Sinon_-"Priam, why art thou old and yet not wise? / For every tear he falls a Trojan bleeds" (1550-551)—she is really asking why she listened to Tarquin. Shakespeare does not deny the power of words, the puissance of the tongue. Indeed, the narrator claims that if not for "Nestor's golden words, / It seem'd they would debate with angry swords" (1420-421). The tapestry is an 
artistic conflation of sight and sound; not only does it "tell" a story, the painter was

skillful enough to depict oration visually:

There pleading [orating] might you see grave Nestor stand, As 'twere encouraging the Greeks to fight,

Making such sober action with his hand

That it beguil'd attention, charm'd the sight;

In speech, it seem'd his beard all silver white

Wagg'd up and down, and from his lips did fly

Thin winding breath which purl'd up to the sky. (1401-407)

Again, words may be potent, but they are false, and hence, untrustworthy:

About him were a press of gaping faces,

Which seem'd to swallow up his sound advice,

All jointly list'ning, but with several graces,

As if some mermaid did their ears entice. (1408-411)

True expression is a result of the coupling both of the visual and the vocal.

Lucrece feels that Hecuba suffers more because she is unable to communicate her grief through words:

On this sad shadow Lucrece spends her eyes, And shapes her sorrow to the beldam's woes, Who nothing wants to answer her but cries

And bitter words to ban her cruel foes;

The painter was no god to lend her those,

And therefore Lucrece swears he did her wrong,

To give her so much grief, and not a tongue. (1457-463)

Lucrece has become the transcendent storyteller. She takes on the poet's role by singing

Hecuba's tale herself:

'Poor instrument,' quoth she, 'without a sound,

I'll tune thy woes with my lamenting tongue,

And drop sweet balm in Priam's painted wound,

And rail on Pyrrhus that hath done him wrong,

And with my tears quench Troy that burns so long,

And with my knife scratch out the angry eyes

Of all the Greeks that are thine enemies. (1464-470) 
Ekphrasis is defined by Jean Hugstrum as "'that special quality of giving voice and language to the otherwise mute art object"" (Scott 29). Shakespeare's "digression," is self-conscious, and hence doubly ekphrastic: the poet gives voice to a mute artwork, and Lucrece gives voice to a mute figure in that mute artwork.

However, as the quote indicates, Lucrece will also take physical revenge; she becomes enraged and claws at the tapestry:

Here all enrag'd, such passion her assails, That patience is quite beaten from her breast.

She tears the senseless Sinon with her nails, Comparing him to that unhappy guest

Whose deed hath made herself herself detest. (1562-566)

According to Scott, Aristotle's term, catharsis, "relies precisely on movement, on a therapeutic release or purging of emotion from the body. In both cases-the play and the audience-stasis [as of the ekphrastic digression] is to be avoided at all costs" (33-34). Ekphrasis, in other words, is seen as digressive, ornamental and stagnant, and hence detrimental to the flow of the story and the catalyzation of catharsis. However, Shakespeare's ekphrasis in The Rape of Lucrece is a therapeutic release-for both Lucrece and the audience. It is at this point that Lucrece finally capitulates to her primal, animalistic instinct; after such long-held composure, she finally exhibits her inner rage by clawing at the figure of Sinon in the tapestry. That exhibition of wild grief is perhaps longer anticipated by the audience, then by Lucrece herself. When the audience/readers finally "see" Lucrece's reaction to the rape, it is an instance of catharsis par-excellance. Lucrece beckons a pedantic attention to detail, and the ability to "see" the visual kaleidoscope beyond/beneath the black and white printed text. In ekphrasis, there is 
always a sense of competition; Leonardo da Vinci named this "competition between the arts" paragone (Scott 30):

Even with the knowledge that texts and images may occupy the same semiotic ground, that there is ample room within the realm of representation for an imaginative détente, critics seem reluctant to comprehend ekphrasis as anything more than a dubious trompe l'oeil. (Scott 38)

However, though poetic and visual representation may seem to vie for control in Lucrece; in actuality, there is no segregation between the sister arts, but a blending of palette and quill, woven cloth and fresh ink, sight and sound. Lucrece is both audience and actor, orator and impersonator; she both gives the Trojan figures voice and adopts their demeanors, their show:

Here feelingly she weeps Troy's painted woes,

So Lucrece set a-work, sad tales doth tell

To pencill'd pensiveness and colour'd sorrow:

She lends them words, and their looks doth borrow. (1492-498)

Is this but a dress rehearsal? Does she borrow their looks to use them in her own grand production? Bromley claims that "if there is a sense that she has staged this final scene, this is due not to a defect of her nature but to her careful purpose. It is an expression of her power, her ability to effect action through words" (208).

\section{The Body and Religion: Lucrece's "Crucifixion"}

Even though Renaissance writers revered Ancient Rome, they by no means abandoned the cross in favor of the caduceus. Far from being at odds with each other, Christian and Classical images are woven together, in the texts of the period, to create a multi-textured fabric - the fabric of the Renaissance. Lucrece is typically Renaissance, in 
that it is a fusion of mythological and religious realms: of Pagan Classical Rome and Protestant Elizabethan England. Just as mythological references abound, "Christian terminology and Christian thinking constantly recur throughout the poem": "There is talk of heaven and hell, of saints and sinners and angels and devils, of grace and gracelessness. ... and both Tarquin and Lucrece express anxiety about the salvation of their immortal souls" (Donaldson 45). The fusion, however, between mythological and religious references, generates anxiety, according to Donaldson, about how the poem, and Lucrece, should be read: "One of the difficulties of Shakespeare's poem is that it is never made clear whether we are to judge the actions of the characters by Roman or by Christian standards; nor is it even clear what kind of moral universe they inhabit" (45). At the center of the debate is always Lucrece's suicide.

"Lucretia, like many other pagan heroes and heroines," claims Donaldson, "is seen as someone whose behaviour cannot easily be accommodated to the Christian religion, but rather stands at variance to it" (29). The skepticism was initiated by Saint Augustine's The City of $G-d$ (c.413 AD), which in part questions the motives behind Lucrece's suicide. In his eyes, to commit suicide after rape-to escape scandal—was merely to commit one sin in order to avoid another (30). For Augustine, "Lucretia's suicide is not a heroic act, but an act of murder": "The notion of suicide as self-murder is central to the development of Christian opposition to the practice. Suicide was often regarded by Christians as being even more heinous than murder" (Donaldson 31). Laura G. Bromley's “Lucrece's Re-Creation," asserts that a plethora of critics, including D.C. Allen and A. C. Hamilton, "see Lucrece as condemned by Shakespeare for being too Roman in her values, a woman who confuses guilt and shame and is, in St. Augustine's 
words, 'too greedy of praise.' (200). But, does Shakespeare truly condemn Lucrece just because the work is permeated with Christian references?

Even if suicide was expected, and considered honorable, in pre-Christian society, Shakespeare's Lucrece did not choose "self-murder" because it was expected of her. Quite the contrary. In the face of the Roman men who claim that the need for suicide is unwarranted, Lucrece consciously chooses to kill herself. Indeed, Donaldson asserts, the fact that she [Lucrece] will kill herself despite their [the Roman men's] assurances that her death is not demanded by logic or necessity is a sign of Lucretia's moral perfectionism rather than her moral fallibility. Her death is indeed the ultimate sign of her innocence, her crowning act of virtue" ([emphasis added]22).

Ironically enough, suicide as a sign of martyrdom also finds its origin in the Christian church.

Early Christians found no dilemma in Lucretia's suicide. In fact, "Lucretia takes her place in both Jerome's and Tertullian's lists of admirable women, pagan and Christian [because] the very high value placed on virginity made female martyrdom a subject of particular interest to the Church" (Donaldson 25-26). As a result, "many Christian women ... were renowned for acting with Lucretia-like resolution" (Donaldson 26). Even in the ages succeeding Augustine, "Lucretia's reputation as a virtuous pagan is never wholly eclipsed" and she is often depicted iconographically, not only as a Christian martyr-as she is in Francesco Trevisani's portrait which depicts her with "one arm flamboyantly aloft, eyes cast imploringly to heaven, her coronet of pearls discreetly suggestive of the crown of life her virtuous actions may have won her" (Donaldson 27)but as a pseudo-Christ figure. In Marcantonio Raimondi's dying Lucretia (c.1511-12), for 
example, her "arms are widely outstretched, her head averted and eyes closed in a manner likely to remind us of the crucified Christ" (27).

Lucretia was glorified not only in the visual arts, but in the printed word.

Donaldson claims that in numerous Renaissance texts dealing with the lives of virtuous women, "Lucretia's suicide is . . ingeniously assimilated into the ethical and imaginative framework of the Christian religion" (27). The Jesuit writer Pierre Le Moyne's La Gallerie des femmes fortes (1667), for instance, "mystically contemplates the nature and significance of Lucretia's wound, musing whether a light may have issued from her blood to irradiate the cloud of her shame, and picturing Lucretia as forced, like Christ, to die more than once in order to convince unbelievers of her virtue" (Donaldson 27). Even in modern times, the image of a christianized Lucretia prevails, as for example in Ronald Duncan's libretto for Benjamin Britten's opera, The Rape of Lucretia (1946) in which her death is likened to Christ's crucifixion, which was "another willing martyrdom intended (though in another way) to wash away the offences of the past and restore an earlier image of pristine virtue" (27-28). Chaucer's version of the Lucrece myth ends with an afterthought which also links Lucrece with the prototypical martyr:

And well I know that Christ himself did say That in the land of Israel nowhere Did he find faith so great as to compare With that of woman; and this is no lie. (1879-882)

Amidst all the texts which link women with the demonic, because of their supposed inherent carnality, there remained a great number which linked women with the divine because of their inherent spirituality. 
Such arguments underscore not only Lucretia's virtue, but her power. She has, like Christ, the strength to overcome the evil that prevails, and the resolution to sacrifice herself to cleanse both her body and the state body, from impurity. Lucrece, as a Christian figure, just as a mythological figure, remains an agent in her own fate. It is thus appropriate that in a painting by Botticelli,

a statue of David holding the head of Goliath stands high above the dead Lucretia in the Forum; near David is Judith with the head of Holofernes. Judith and Lucretia are joined as women of power, who in their different ways manage, despite their apparent frailty, to bring down their enemies, as David brings down Goliath .... Despite her apparent passivity, subservience, and self-destruction, Lucretia is the ultimate victor. (Donaldson 18)

Decapitation, which, as discussed, often symbolized the threat of malevolent female power because of its Freudian connection with castration and Medusa, could simultaneously symbolize benevolent, Christian, female power and the destruction of evil. Corporeal images in the poem, then, attest not only to Lucrece's innocence, but to her strength of character.

Critics often argue that after the rape, Lucrece becomes a "castaway," "the common theological term for a lost soul" (Donaldson 46), and that "the rest of the poem [after the rape] shows Lucrece's attempts to re-create herself in a 'wilderness where are no laws' (1.544)” (Bromley 204). Laura G. Bromley’s “Lucrece's Re-Creation,” asserts that "it is this fallen state that Lucrece inherits" (205). She claims, however, that "not by concealing, but only by revealing what is within-her corruption and her grief-can Lucrece transcend her own divided nature" ([emphasis added] 207). Again, exposure is of the utmost importance. So too is bodily exposure. In fact, Rosemary Haughton's Beginning Life in Christ argues that "“Christianity is, far more than any other, a physical 
religion, which is one reason why many spiritually minded people find it gross and fleshly, and try to refine it and 'spiritualize' it . But it is inescapably 'fleshly,' being founded in the human flesh of . . . Christ" (qtd. in Tilley 194). Maureen A. Tilley and Susan A. Ross maintain a similar position: "The writings of the earliest Christians were permeated with language about the body, with language about the broken and the whole. This should be no surprise in a religion which professes the incarnation, the embodiment, of the Divine" (Tilley vi-vii).

\section{The Hand of G-d}

Just as for Lucrece the rape "hath made herself herself detest" (1562-566), so too is Tarquin torn between parts of the self:

Pawning his honour to obtain his lust; And for himself himself he must forsake. Then where is truth if there be no self-trust? When shall he think to find a stranger just, When he himself himself confounds ... ([emphases added]156-60)

Like Richard III, whose fractured psyche is illustrated by statements such as, "Richard loves Richard; that is, I am I" (Shakespeare 5.3.183), the narrator's repetitive use of "himself," in Lucrece, underscores Tarquin's dichotomous inner battle and the fragmentation of the self. The ensuing descriptions of Night's ghoulish entourage indicate, however, that the outcome of the strife is a capitulation, literally, to the dark side:

No noise but owls' and wolves' death-boding cries;

Now serves the season that they may surprise

The silly lambs: pure thoughts are dead and still, While lust and murder wakes to stain and kill. (165-68) 
Lucrece is "this earthly saint adored by this devil" (85), "that which is divine" (193), and a pure "shrine" (194). When she decides on suicide it is in order to free her soul from a wracked body:

Ay me, the bark pill'd from the lofty pine, His leaves will wither and his sap decay;

So must my soul, her bark being pill'd away.

'Her house is sack'd, her quiet interrupted, Her mansion batter'd by the enemy, Her sacred temple spotted, spoil'd, corrupted, Grossly engirt with daring infamy. Then let it not be call'd impiety, If in this blemish'd fort I make some hole, Through which I may convey this troubled soul. ([emphasis added] 1167-176)

Again, the initial exposure-invasion/penetration—leads her to expose herself by making a "hole" in her body with the dagger. But more importantly, her body is not only a fortress, but a temple.

Tarquin, on the other hand, belongs to the world of witchcraft. In fact, when he claims that "thoughts are but dreams till their effects be tried; / The blackest sin is cleared with absolution" (353-54), he "consciously abandoned both reason and faith, claiming both ignorance of evil before the fact and exemption from evil after the fact" (Bromley 205). Moreover, Bromley asserts, he "recognized as blasphemy his appeal for heaven to bless his enterprise; but, purposely blind to moral order, he invoked love and fortune as his gods" (205).

Shakespeare may have adhered to the Augustinian belief that sin has everything to do with intent and little to do with action since Tarquin "Into the chamber wickedly ... stalks, / And gazeth on her yet unstained bed" ([emphasis added] 365-66). He is wicked, 
or walks wickedly, before any act is really committed.. Tarquin's hand is, likewise, already deemed guilty before any act of violence is committed: "his guilty hand pluck'd up the latch" ([emphasis added] 358). The fact that it is his hand which is guilty is significant. According to Katherine Rowe's “G-d's Handy Worke,” both Galen and Columbus dissected the body in a particular sequence, giving pride of place to the hand in order to reflect its "preeminence as a part": "Galen famously begins De usu partium with the hand ... because it is the ideal and exemplar of all other parts; and Columbus treats the hand last for a related reason: 'because ... the wonderfull and miraculous frame thereof might remaine infixed in our memories' (785)" (Mazzio 290). But, why does the hand transcend the rest? Because, asserts Rowe, the hand links "divine intentions and the work of civilizations," i.e., the hand builds churches, writes laws, creates artwork, and because its beauty is proof of divine design (Mazzio 292). In other words, the hand both does G-d's work and is G-d's work.

Moreover, the hand is "the location of agency" in our body, and so it was often used pictorially to represent G-d's agency:

Illustrations of the arms, as for example, from Berengario's Commenturia (1521), often draw on an old motif in religious art. G-d's hand emerges from the clouds, sometimes surrounded by a nimbus, often swathed in cloth. The clouds or classical sweep of fabric that circle the shoulder where the limb ends mark the point past which G-d's actions must not and cannot be traced. We can see the evidence of G-d's work on earth (denoted by the reaching hand), but G-d's person and intentions remain inscrutable. (Mazzio 303)

Therefore, like the breast in Petrarchan love poetry_-which is the last detailed feature and is meant, through metonym to represent "the rest"-the arm, in Christian contexts also often represents all that cannot be seen-the beyond. The fact, then, that Tarquin's hands 
are guilty before he has raped Lucrece may be indicative of the fact that he has already fallen.

In the poem, great lengths are taken to describe both Lucrece's and Tarquin's hands. Tarquin's hands are anything but virtuous: they are pricked by the needle (319), are guilty (358), are like "the gripe's sharp claws" (542), are soldiers given "watch-word" by his "greedy eyeballs" (368-70), are proud-"His eye commends the leading to his hand; / His hand, as proud of such a dignity, / Smoking with pride, march'd on to make his stand" (436-38)—and are a "Rude ram" (464). Lucrece's hands, like all her other parts, on the "other hand", represent her virtue. They are lily (386), fair (393) and are an idyllic "perfect white / [which] Show'd like an April daisy on the grass [the green coverlet], / With pearly sweat resembling dew of night" (394-96). Her hand, which lies under her cheek, protects it from being kissed by the pillow, and so she lies like "a virtuous monument" (386-91). In other words, Lucrece is so chaste, that her hand wards off an unwarranted kiss even from a pillow.

When she decides to commit suicide she speaks directly to her hands:

'Poor hand, why quiver'st thou at this decree?

Honour thyself to rid me of this shame:

For if I die, my honour lives in thee, But if I live, thou liv'st in my defame.

Since thou could'st not defend thy loyal dame, And wast afeard to scratch her wicked foe, Kill both thyself and her for yielding so'. (1030-36)

Lucrece seemingly ascribes to the notion that the hand is the symbol of agency and hence blames her hand for her acquiescence. However, in the presence of the Roman men, she blames Tarquin, saying that it is he who "guides this hand to give this wound to me"" 
(1722). Once again, in the company of the men, she submits to their own stereotypes. She relinquishes her subjectivity/agency to Tarquin-she does not even control her own hand.

Tarquin's hand seems almost paralyzed, as it lays for a lengthy amount of time upon her breast: "His hand that yet remains upon her breast,-— / Rude ram, to batter such an ivory wall!" (463-64). It is as if he tries to possess her by means of his hands; however, Tarquin, like Collantine and Lucretius, does not understand that "heavenly" Lucrece does not belong to any of them. According to Donaldson, "The ultimate possessors of Lucrece's 'treasure,' . . . are 'the heavens'; she is merely 'lent' to Collantine, who fails to realize the true value and the ultimate revocability of the gift" $(50)$ :

For he the night before, in Tarquin's tent Unlock'd the treasure of his happy state:

What priceless wealth the heavens had him lent, In the possession of his beauteous mate. (15-18)

In the poem, Lucrece raises her arm in numerous instances. When Tarquin praises Collantine's "manly chivalry" to gain her favor, for example, Lucrece expresses her joy "with heav'd-up hand" and so "wordless ... greets heaven for his success" (111-12). Likewise, when she attempts to dissuade Tarquin it is with "heav'd up hands" that she appeals (638). In pictorial representations of the rape, such as Titian's Tarquin and Lucretia (c.1570) Lucrece's hand, though raised to fight off her assailant, also seems to call upon Divine assistance. According to Donaldson,

the light catches the very tip of Tarquin's dagger, the tear on Lucretia's cheek, the bracelet on her right arm, which is held aloft as though appealing eloquently to heaven, and-at the exact vertical centre of the painting - the wedding ring on her left hand, which attempts forlornly to ward off her attacker. (13) 
Rowe asserts that "saints are often pictured pointing to the props that symbolize their martyrdom" (293). It is plausible, then, that Shakespeare intended this gesture-which is ubiquitous gesture in both other texts and paintings-to symbolize her martyrdom. However, her hands also characterize her power. Unlike Lavinia of Titus, who is merely the "handmaid of Revenge" (Shakespeare, Titus 12), Lucrece handles her carefully contrived revenge herself.

\section{The Eye of Heaven}

When day breaks after the rape, Lucrece seems to recite a sardonic Aubade, or dawn song - a poem depicting lovers, who must part with the coming of day, and hence,

condemn the sun for its intrusion. ${ }^{5}$ She interrogates the imposing, prying sun:

...'O eye of eyes,

Why pry'st thou through my window? leave thy peeping,

Mock with thy tickling beams eyes that are sleeping;

Brand not my forehead with thy piercing light,

For day hath naught to do what's done by night'. (1088-92)

The pun on the Son/sun rising is a central Christian notion. According to Alan R.

Culpepper's Anatomy of the Fourth Gospel: A Study in Literary Design:

'No one has ever seen [horao] G-d,' the narrator [of the Fourth Gospel] announces in the prologue; it is the Son alone who has made him known $(1: 18 ; 6: 46 ; 8: 38 \mathrm{a} ; 12: 45 ; 14: 8-9 ; 15: 24 \mathrm{~b})$. The Son focuses the radiant glory of the Father and relays it to the believer (cf.11:40; 17:22); therefore, the Son is an eye. 'I am the light [phos] of the world,' declares the eye; 'whoever follows me will never walk in darkness [skotia] but will have the light of life' (8:12; cf.9:5; 1:3-4; 3:19-21; 9:39; 11:9-10; 12:35-36, 40, 46)" (qtd. in Moore 59).

Therefore, she calls the sun the eye of eyes, and night the time when the "eye of heaven is out" (356). If the sun is the eye of G-d, then Lucrece is also somewhat divine since her 
eyes are described in terms similar to the sun: "her eyes like marigolds had sheath'd their light, / And canopied in darkness sweetly lay, / Till they might open to adorn the day" (397-99). Her eyes were not as much sealed in darkness, as when closed, they seal the world in darkness. Her eyes, like the sun, illuminate the earth. They are "mortal stars as bright as heaven's beauties" (13). In fact, through synecdoche, she is that "greater light" (375). Charles Wordworth, D.C.L, in Shakespeare's Knowledge and Use of the Bible, argues that the phrase "greater light" was appropriated directly from the first chapter of Genesis which reads: "“G-d made two great lights; the greater light to rule the day, and the lesser light to rule the night"” (54).

In the description of Lucrece's beauty, Tarquin's eyes do not seem to follow a particular path common to traditional blazons. Instead he moves from her hand, to her cheek, to her eyes, to her hair, to her breasts, to her veins, to her skin, to her lips, and finally, to her chin. Rather than moving from the lowest vertical point to the highest or vice versa, he moves chaotically up and down. It is as if in his painful delight he attempts to view (hence conquer or ravish) all. The hurried, unpatterned, movement of his eyes seems to indicate his unstructured state of mind. He seems ruled by the devilish chaos of passion rather than the order of reason. And though this "virtuous monument" is undoubtedly being "admir'd," it is by "lewd unhallowed eyes" (391-92). Hence, all the harmony of virtue seems to crumble when displayed for the unsacred.

\footnotetext{
${ }^{5}$ For an example of the Aubade, see John Donne's "The Sun Rising" which begins: "Busy old fool, unruly
} 


\section{Knee-Jerking}

Tarquin's opening of the door with his knee, like the other elements of the scene in which he approaches Lucrece's bedchamber, foreshadows the rape. To bend one's knee in the Renaissance, according to Marjorie Garber, meant to give deference to political and social hierarchies:

Of all early modern joints, the knee is arguably the most distinguished, at least in literary terms. The knee is an important articulation of the physical body politic, especially if the physical body politic is male. ... To bend the knee is to give homage, to assent to a political and social contract. Thus the knee in Shakespeare is often a figurative as well as a literal joint, appearing ... in the history plays, both English and Roman. (Mazzio 24)

To bend the knee connotes subservience not only to the State, but to G-d-as in the act of kneeling at the pew to pray. Shakespeare's description of the way Tarquin enters

Lucrece's bedchamber-“with his knee the door he opens wide" (359)—expresses his heretical and anarchical confrontation of those societal and religious powers.

(Shakespeare has Tarquin awkwardly raise his knee—instead of using his shoulder-to knock in the door.)

"But," claims Garber, "the knee as body part does not always connote homage or prayer"(Mazzio 27). Rather, because of its proximity "to the genitals, [it was] often invoked as a kind of euphemism": "Defloration and impregnation are often figured in this period as a breaking of joints-most often knees ..." (Mazzio 27-28). Interestingly enough, within only a few lines of each other are Tarquin's exclamation " I must deflower"' (348) and the opening the door with his knee (359). 


\section{Falling In-Digestion}

One of the most significant and omnipresent Biblical allusions employed in the Renaissance is the Judeo-Christian notion of the Fall from Grace. In Daniel's complaint poem, for instance, Rosamond, in an act of hubris, compares her predicament to Eve's: "For firft we tafte the fruit, then fee our fin. / Now did I finde my felfe vnparadif'd, / From thofe pure fields of my fo cleane beginning" (455-57). She also equates the beguiling serpent with the old woman, about whom she says, "Now I perceiu'd how ill I was aduif' d" (458). This notion is consequential in Shakespeare, but by no means exclusive to The Rape of Lucrece; in fact, Shakespeare uses the Fall in an abundance of other works, including: Richard II, Comedy of Errors, Love's Labour Lost, Two Gentlemen of Verona, Much Ado About Nothing, and As You Like It (Wordsworth 55-58).

"Sonnet 129," Shakespeare's text-book definition of lust, equates lust with appetite. Lust, according to the sonnet, is like indigestion-inducing food; it may taste good going down, but Montezuma's Revenge will come back to haunt you later:

Enjoyed no sooner but despised straight, Past reason hunted, and no sooner had Past reason hated as a swallowed bait On purpose laid to make the taker mad. ([emphasis added] 5-8)

Similarly in Lucrece, Tarquin's immediate guilt after the rape is exemplified by his indigestion-his inability to deal with (to digest) what he has voraciously consumed: "So surfeit-taking Tarquin fares this night. / His taste delicious, in digestion souring, / Devours his will that liv'd by foul devouring" (698-702).

In works of the period, such as Marlowe's Tamburlaine, the devouring of food often equates to power. Since virility is linked with the ability to eat well, Tarquin's 
sensitive stomach is a sign of his effeminacy, and therefore, his inability to govern successfully. ${ }^{6}$ However, there is much more at stake here than masculinity.

Rapaciousness is not only associated with power, but with heretical power. Balance and moderation is godly even in relation to digestion, which is often linked in the Renaissance to divinity. In his chapter entitled "Fables of the Belly in Early Modern England," Michael Schoenfeldt cites Van Helmont's Paradoxical Discourses (translated into English in 1685). In the work, Helmont argues that the stomach is not only "a literal location of divinity," but moreover, "the holiest of holies" (225):

Forasmuch as the Body of Man, according to the testimony of Scripture, is, and should be the Temple of G-d. ... And that in the Temple at Jerusalem, there was an Altar of Burnt-offering, upon which many Beasts, $\& C$. was offered: and seeing that all the meat a man feeds upon enters in to the stomach, might not the stomach be compared with the said Altar? And might it not properly be called an Altar in the Temple of G-d, on which all right and well ordered food for the life of man, is to be offered up? (255)

According to Schoenfeldt, this belief is enacted in the Eucharistic meal where "the stomach is . . the receiving chamber in which G-d is welcomed into the temple of the self" (Mazzio 255).

But, what has this to do with Tarquin and his indigestion? Schoenfeldt helps elucidate with his discussion of Paradise Lost:

Milton not only 'images forth the cosmos as a vast anthropomorphic digestive system' but also reminds us repeatedly that the originary myth of western culture is a narrative of dietary transgression. After Adam and Eve eat the forbidden fruit and take 'their fill of love and love's disport' ... they fall asleep, and experience the first terrestrial case of insomnia caused by indigestion. ... One of the bitterest jokes suffusing Milton's portrait of the Fall is the indigestion it causes" (256).

\footnotetext{
${ }^{6}$ Renaissance dramas, such as Shakespeare's Richard II and Marlowe's Edward II, employ effeminacy as a trait characteristic of a weak monarch.
} 
The gluttonous terms used to describe Tarquin immediately after the corrupting act-a "full-fed hound" and a "gorged hawk" ([emphasis added] 694)—lead to terms suggesting purgation: "Drunken desire must vomit his receipt" ([emphasis added] 703). His sour stomach attests to his fall from grace; he is "purged" from innocence. Again, Shakespeare's Elizabethan Protestant audience—and more specifically, the elite, erudite readers of his poetry - would be able, without difficulty, to decipher the Biblical allusions.

Conceivably, it is not by coincidence that immediately following the segment on Tarquin's indigestion is a discussion about the destruction of his soul:

... his soul's fair temple is defaced, She says her subjects with foul insurrection Have batter'd down her consecrated wall, And by their mortal fault brought in subjection Her immortality, and made her thrall To living death and pain perpetual. (719-26)

His soul's protection, a wall, has been penetrated. In a sense, his soul has been raped by his passions, by his act of rape. And so, he is a "captive victor that hath lost in gain" and must bear "away the wound that nothing healeth, / The scar that will despite of cure remain" (730-32). Violence, as the adage goes, begets violence: "The sweets we wish for turn to loathed sours / Even in the moment that we call them ours" ([emphasis added] 867-68). No more is he the proud issue of a king, rather, he is "a thievish dog" who sweats “with guilty fear” $(736,740)$. According to Donaldson, “Tarquin has lost something more important than either Lucrece or Rome. The vital loss is not material but spiritual. ... it is almost as though, in a spiritual sense, Tarquin had raped himself. Rape 
is seen not merely as destructive, but also as a self-destructive act" (52). So, while

Lucrece is ubiquitously characterized as heaven - the chamber door "shuts him from the heaven of his thought, / Which with a yielding latch, and with no more, / Hath barr'd him from the blessed thing he sought" (337-40)—Tarquin is undoubtedly hell. "What Tarquin has gained," claims Donaldson, "is a sense of guilt and probability of damnation" (53).

\section{The Disembodied Hell/en of Troy}

\section{Marlowe's Doctor Faustus}

In Daniel's complaint poem, Rosamond narrates Amymone and Neptune's tale after finding them engraved upon the lid of the casket:

Amymone, old Danaus faireft Daughter, As fhe was fetching water all alone

At Lerna: whereas Neptune came and caught her:

From whom fhe ftriu'd and ftruggled to be gone, Beating the aire with cries and piteous mone;

But all in vaine, with him fhe's forc'd to go. (386-91)

A intriguing difference between Rosamond and Lucrece is that, while the former empathizes with the ravished Amymone depicted on the casket, the latter disassociates herself from the ravished Helen depicted on the tapestry. Lucrece goes so far as to call her "the strumpet that began this stir" and wants to tear Helen's beauty with her nails $(1471-472)$.

Lucrece condemns Helen for provoking Paris with her lust:

'Thy heat of lust, fond Paris, did incu

This load of wrath that burning Troy doth bear; 
Thy eye kindled the fire that burneth here, And here in Troy, for trespass of thine eye, The sire, the son, the dame and daughter die. (1473-477)

She seems to have come full circle-from victim to victimizer-in her heartless denunciation of Helen. She does whatever need be to disassociate her own situation from Helen's. But why would Lucrece so adamantly disengage herself from another ravished woman?

Though undeniably influenced by Ovid, Livy, Chaucer and Daniel, Shakespeare's greatest influence was also his rival-Christopher Marlowe. Shakespeare's description of Troy as "cloud-kissing Ilion" (1370), comes, as the footnote indicates, from Marlowe, and appears in Doctor Faustus $(D F)$ as "the topless towers of Ilium" (128). However, that is far from the only parallel. In The Anxiety of Influence, Harold Bloom asserts that "Shakespeare experienced an anxiety of influence in regard to his prime precursor and rival Ovidian, Christopher Marlowe, only two months or so older than Shakespeare but the dominant London playwright from 1587 until his violent death in 1593, aged twentynine" (xx). Critics, like Bloom, have already forcibly argued that Marlowe "was crucial to Shakespeare's art from the early tetrology of the three parts of Henry VI and Richard III (1589-93) through Titus Andronicus (1594) until Shakespeare surmounted Marlowe's Edward II in Richard II (1595), two years after Marlowe was murdered in a tavern brawl" (Influence xxi). But, relatively little has been said of the relationship between Shakespeare's poem and Marlowe's play.

Though there may not seem to be few affinities between Shakespeare's poem about the rape of a Roman woman and Marlowe's play about the ravishment of a German doctor, there are a myriad. Numerous concerns in Lucrece (c.1594) find their parallel in 
Faustus (c.1588-9): ravishment/rape, free-will, shame, pride, language, spectacle, and more importantly to this discussion, the body in parts, dismemberment and Helen of Troy. Hence, Doctor Faustus will be used as a hermeneutic tool to help excavate meaning in Lucrece.

\section{Body Parts}

\section{The Stomach}

The notion of the Fall is as much an issue in Faustus as it is in Lucrece. According to Bevington and Rasmussen,

Faustus's mythical ancestry is widely dispersed in Christian and classical lore. The Book of Genesis tells of humanity's first disobedience towards G-d, through a choice that opens the eyes of humanity to the knowledge of good and evil and thus forfeits all right to paradise. The choice is both an act of hubris and quintessentially human. In Greek mythology, Prometheus and Icarus prefigure Faustus's championship of human selfassertion and the punishment that inevitably follows. (Marlowe 7).

While Lucrece as a woman is merely wax into which the devil (Tarquin, man's evils) is stamped, Faustus is affiliated with Icarus who with wax wings tried to surmount the heavens and literally Fell:

... swoll'n with cunning of a self-conceit, His waxen wings did mount above his reach, And melting, heavens conspired his overthrow. For, falling to a devilish exercise, And glutted now with learning's golden gifts, He surfeits upon cursed necromancy. ([emphasis added] Prologue 19-24) 
Faustus, Bevington and Rasmussen contend, "vaingloriously chooses to emulate G-d as a rival and to preoccupy himself with his own 'ascension above humanity"' (Marlowe 18).

It is this Icarus complex, this pride, which adjoins him with Tarquin (and Lucifer).

Pride appears in Doctor Faustus as one of the Seven Deadly Sins, and his speech indicates that the sin involves licentiousness:

... I am like to

Ovid's flea: I can creep into every corner of a wench.

Sometimes like a periwig I sit upon her brow; next, like a necklace I hang about her neck; then, like a fan of feathers I kiss her, and then, turning myself to a wrought smock, do what I list. ... (2.3.111-15).

There is no doubt as to the meaning behind the "corners" of a wench. However, pride more importantly manifests itself in gluttony, personified as another of the Seven Sins:

[My] father was a gammon of bacon, and my mother was a hogshead of claret wine. My godfathers were these: Peter Pickled-herring and Martin Martlemas-beef. But my godmother, $\mathrm{O}$, she was an ancient gentlewoman; her name was margery March-beer. Now, Faustus, thou hast heard all my progeny, wilt thou bid me to supper? (2.3.146-51).

Indeed, food is omnipresent throughout the play: the Pope is overly concerned with "dainty dishes" and requests a banquet to " solemnise Saint Peter's feast" (3.2.19899); Faustus is "glutted with conceit" (1.1.77); Carter complains that Faustus ate a whole load of hay for three farthings (4.5.24-31); Robin and Dick offer Mephistopheles a shoulder of mutton when they conjure him (3.3.38-40); the pregnant Duchess requests "no better meat than a dish of ripe grapes" (4.6.17-18); and the macabre disclosure of hell involves "Furies tossing damned souls / On burning forks" (5.2.123-24). As in Lucrece, in Faustus, "Verbal metaphors in the play of devouring and of surfeit draw upon iconographical traditions showing gluttony to be 'the fault of Adam' and the repudiation 
of gluttony the first victory of Christ's temptation in the wilderness" (Marlowe 19). In both works, insatiability—and the stomach—is indicative of a fall from grace.

\section{The Tongue}

Digestion, however, begins with the mouth, and consequently, the tongue/language is also involved in the fall. Cornelius tells Faustus that he is "enriched with tongues" and so "hath all the principles magic doth require" ([emphasis added] 1.1.132-34). Indeed, the first thing Cornelius and Valdes teach Faustus are the "words of art" (1.1.152-53). When Faustus is successful in invoking Mephistopheles, he says, "I see there's virtue in my heavenly words" ([emphasis added] 1.3.28). Of course, Faustus's words are anything but heavenly. According to Bevington and Rasmussen, "Contrasts abound in the play's discourse. ... His [Faustus's'] fascination with logic, derived no doubt from Marlowe's own intellectual experience at Cambridge, shows what is simultaneously exalted and debased in Faustus's view of human aspiration through language" (Marlowe 39). Furthermore,

since Mephistopheles and his fellow devils are also capable of linguistic cunning, the very project of language through which Faustus dares to assert human greatness is doomed by his perversion of the gift of language. As William Blackburn insists, 'not magic, but the magician, is on trial here; the play 'is Marlowe's metaphor, not for the failure of language as an instrument of transformation, but for man's failure to understand it and use it wisely.' At the same time, we are invited to sympathize with a protagonist who discovers to his cost the ambiguous power of speech. (Marlowe 39)

Interestingly, and in line with this train of thought, it is literally the "jaws of hell" which open to receive Faustus (5.2.120): "Hellmouths, in medieval illustration and theatrical practice, were often visualised [sic] as huge, scaly, sharp-toothed heads of leviathans, 
within whose gaping jaws could be seen the devils of hell and their victims in grotesque postures of torture" (footnote 282).

As if to reinforce the ambiguous nature of language, Marlowe make sure that the spirits, summoned for Faustus and his company's entertainment, do not speak. As for example when Faustus invokes Helen. He says, "Be silent ... for danger is in words" (5.1.26). And when he calls upon Alexander and his paramour, he warns the Emperor not to question him, "but in dumb silence let them come and go" (4.1.96). Furthermore, when Faustus has had enough of Carter, the Horse-courser, Dick, and Robin he gets rid of them by charming them dumb (4.6.110-20).

\section{The Eye}

The Emperor asks, since he cannot speak to Alexander and his paramour, if he could at least look for a mole that she was thought to have when she lived. The Emperor unable to find proof in words, looks for physical proof. Upon finding it he says: "Faustus, I see it plain, / And in this sight thou better pleasest me / Than if I gained another monarchy" (4.1.115-17). Indeed, Faustus wants not only the power of words, but wants to "be a divine in show" (1.1.3). He says, "in this show let me an actor be, / That this proud Pope may Faustus' cunning see" (3.1.75-76). Faustus and Mephistopheles assume the shapes of two cardinals, thereby taking acting to its extreme in literal ventriloquism or puppeteering: "make them sleep so sound that in their shapes / Thyself and I may parley with this Pope" (3.1.116-17). Faustus is also made invisible with a spell that calls on mythological witches:

The planets seven, the gloomy air, Hell, and the Furies' forked hair, Pluto's blue fire, and Hecate's tree 
With magic spells so compass thee

That no eye may thy body see. ([emphasis added] 3.2.19-23)

Benvolio, in insulting Faustus, says, "He looks as / like a conjurer as the Pope to a costermonger" (4.1.72-73). Appearance in Faustus as in Lucrece, is never what it seems.

\section{Dismemberment}

Faustus is dismembered by the devils at the end of the play. But, he is also dismembered throughout in jest. According to Bevington and Rasmussen,

The comic scenes, with their emphasis on dismemberment and curing, recall the action of folk plays, especially of the swordplay type. The play's vernacular roots go back to burlesque rituals of communal gargantuan feeding as found earlier in The Secunda Pastorum and other cycle plays, and to country mummings of the 'eldritch' type in which the grotesque comedy of false limbs and severed heads borders on the demonic. (Marlowe 15)

However, for a more prevalent source for ritualized dismemberment, one need look no further than the Renaissance practice of public execution. Jonathan Bate offers a typical sentence passed on a nobleman found guilty of treason in 1589: he should " "be hanged until he were half dead, his Members to be cut off, his Bowels to be cast into the Fire, his Head to be cut off, his Quarters to be divided into four several parts, and to be bestowed in four several places"” (Shakespeare, Titus 23-24). In fact, argues Bate, "the resemblances between tragedy of blood and live execution did not escape notice in the period"(Shakespeare, Titus 24):

in Basilicon Doron, James I famously wrote that 'a King is as one set on a skaffold, whose smallest actions and gestures all the people gazingly doe behold,' but in later editions 'skaffold,' with its simultaneous summoning of theatre and place of execution, was changed to 'stage'. (Shakespeare, Titus 24) 
Such dismemberment takes us very close not only to the world of Titus Andronicus-in which Lucius says: "Give us the proudest prisoner of the Goths, / That we may hew his limbs on a pile" (1.1.99-100)—but to the worlds of The Rape of Lucrece and Doctor Faustus.

In Titus, Tamora threatens Bassianus that if she had the power, she would transform him into Actaeon: "Thy temples should be planted presently / With horns, as was Actaeon's, and the hounds / Should drive upon thy new-transformed limbs" (2.2.6164). Likewise, in $D F$, Benvolio, skeptical of Faustus's powers, jests that if the conjurer is able to invoke Alexander, then he will turn himself into an Acteon-like stag: "An thou bring Alexander and his paramour before the Emperor, I'll be Actaeon and turn myself to a stag” (4.1.98-100). Faustus's reply is, “And I'll play Diana and send you the horns / presently" (4.1.101-2). According to myth, Actaeon unintentionally stumbled onto Diana as she was washing herself in a stream. He was punished, for seeing the goddess naked, by being transformed into a stag. According to Ovid's Metamorphosis, Acteon was metamorphosed into a beast to prohibit him from talking, from revealing to others what he had seen: "'If you can talk, then speak, / Say that you saw Diana in undress.' / And as she spoke his wet hair branched in antlers" (90). Moreover, as a stag, he was dismembered by his own hunting dogs. In other words, his tongue was first metaphorically dismembered, followed by the literal dismemberment of his body.

In a following scene, Frederick, Benvolio and Martino plan to strike off Faustus's head in return for their humiliation. When they think they have succeeded in doing so, they discuss other ways they plan to dismember him:

Benvolio. First, on his head, in quittance of my wrongs, 
I'll nail huge forked horns and let them hang

Within the window where he yoked me first

Martino. What use shall we put his beard to?

Benvolio. We'll sell it to a chimney-sweeper. It will wear out ten birchen brooms, I warrant you.

Frederick. What shall his eyes do?

Benvolio. We'll put out his eyes, and they shall serve for

buttons to his lips to keep his tongue from catching cold.

Martino. An excellent policy. And now, sirs, having divided

him, what shall the body do? (4.2.55-66)

Faustus's punishment for them is that they will, in return, also be dismembered. First they will be separated from each other-some hurled into mud, others rolled down steep rocks. Then he will break their bones; they will be crushed: "This traitor flies unto some steepy rock / That, rolling down, may break the villian's bones / As he intended to dismember me" (4.2.89-91).

Faustus then "pulls" another dismembering trick. Faustus sells the Horse-courser a horse for forty dollars and warns him not to ride it over water. The Horse-courser, thinking it had magic powers, rides it over water anyway, and the horse turns into straw. When he returns to Faustus to fight for his money back, he tries to wake the apparently sleeping magician by pulling on his leg. He pulls so firmly, that he yanks the limb right off:

Doctor, awake and rise, and give me my money again, for your horse is turned to a bottle of hay. Master Doctor! (He pulls off his leg.) Alas, I am undone! What shall I do? I have pulled off his leg.

Faustus. O, help, help! The villain hath murdered me.

Horse-courser. Murder or not murder, now he has but one leg

I'll outrun him and cast this leg into some ditch or other.

Faustus. Stop him, stop him, stop him!-Ha, ha, ha! Faustus hath his leg again, and the Horse-courser a bundle of hay for his forty dollars. (4.4.35-45) 
When the Horse-courser meets Faustus again in Act 5, scene 4, he thinks that the magician must now have a wooden leg; when Faustus proves him wrong by curtsying, the men asks: "Had the doctor three legs?" (109). Modern readers, of course, cannot help but think of the phrase "a third leg" in reference to the penis. But, why did Marlowe invest so much "legwork" into the leg?

To gain an understanding of the importance of the leg/foot, readers should look back at a previous scene. In Act 3, scene 1, Pope Adrian enters with Raymond, king of Hungary, and Brutus, the rival Pope, in chains. Pope Adrian says "Cast down our footstool" and Raymond continues, "Saxon Bruno, stoop, / Whilst on thy back his Holiness ascends / Saint Peter's chair and state pontifical" (88-91). Bruno is a footstool, upon which Pope Adrian will figuratively step into Saint Peter's chair and become the newly-appointed Pope. The dramatization of Bruno's humiliation, according to the footnote, "is loosely based on John Foxe's Acts and Monuments, II. 195-6. Foxe tells of a confrontation between Pope Alexander (1159-81) and the Emperor Frederick Barbarossa, in which Frederick set up a rival pope, Victor IV, but was forced to submit and place his neck under the papal foot. (236)

In Peter Stallybrass's chapter in The Body in Parts: Fantasies of Corporeality in Early Modern Europe, entitled "Footnotes," he claims that "in early modern Europe, power is marked not by the absence of feet but by their presence. Marlowe's Tamburlaine makes his enemies his footstool; he puts his feet upon them" (314). Stallybrass explains that the image derives from the Bible: “'The Lord said vnto my Lord, Sit thou at my right hand, vntil I make thine enemies thy fotestole.' In Isiah, the Lord's power is repeatedly 
invoked as his ability to tread down his enemy: 'vpon my mountaines wil I treade him vnder fote' (14.25)" (Mazzio 314). "Feet in the Renaissance," asserts Stallybrass, "measures the person. ... To know a person is to know his or her foot" (Mazzio 315). Furthermore, "They are the body's essential support, emblems of firmitas and soliditas" (Mazzio 315). Therefore, Faustus's leg trick disinters, through synecdoche, a pun on Fall/fall: Faustus will Fall from Grace just as surely as his body would literally fall without the support of its legs.

It is interesting that Faustus was given the option by the devils to stab himself. It is only the Old Man who dissuades him. The Evil Angel ominously warns him, 'If thou repent, devils shall [will] tear thee in pieces' (2.3.81). Mephistopheles himself also threatens that if he does not revolt against G-d, he will be torn apart: "Thou traitor, Faustus, I arrest thy soul / For disobedience to my sovereign lord. / Revolt, or I'll in piecemeal tear thy flesh" (5.1.69-71). An half an hour before his death, Faustus calls upon the stars:

Now draw up Faustus like a foggy mist Into the entrails of yon labouring cloud, That when you vomit forth into the air, My limbs may issue from your smoky mouths, But let my soul mount and ascend to heaven. (5.2.162-66)

Faustus, in the end, is dismembered by the devils: "here are Faustus's limbs, / All torn asunder by the hand of death" (5.3.6-7). There is of course a play upon the dismembered limbs and hand of death. When the scholars tell Faustus that it is never too late to repent he says he cannot: "I would lift up my hands, but see, they hold 'em, they / hold 'em" (5.2.62-3). The devils hold down his arms. Unlike Lucrece, whose arms seem constantly raised - which denotes a connection with the heavens-Faustus, damned, who will be 
dismembered by the hand of death, cannot raise his hands. According to Bevington and Rasmussen, “The B-text makes a good deal of Faustus's physical dismemberment at the moment of his death, thereby bringing to fulfilment [sic] a pattern of a dismemberment evoked in both texts of the play" (Marlowe 46)

\section{The Demonization of Helen: Dishonor/Dismemberment}

A reader of Christopher Marlowe's Doctor Faustus $(D F)$ is bound to question the significance of the infamous Helen of Troy's brief cameo in Act V. Indeed, how does this Greek archetypal beauty fit into the German, necromantic world of devils and damnation that is $D F$ and what has she to do with Lucrece/Lucrece? Helen and Lucrece's paths actually cross more than might be expected. First of all, according to The Lawes Resolution of Womens Rights (1632), there are two kinds of rape: the first is " "when a woman is enforced violently to sustaine the furie of brutish concupiscence: but she is left where she is found"' and "the second, simply as her removal (regardless of any sexual consequences)" (qtd. in Catty 13). This leads, of course, to the differentiation between rape and ravishment. Interestingly, though, the author of The Lawes "cites Lucrece as the paradigm of the woman forcibly violated without being abducted, but for his second model cites Helen: certainly the paradigmatic stolen woman, but one whose volition in the removal and its sexual consequences is highly ambiguous" (Catty 13).

Second of all, Lucrece is not the only of the two to be immortalized in a "female complaint." Indeed, alongside the royal mistresses and martyrs, "there are also a number of explicit "whores"' (Catty 62), and Helen, according to Catty, frequently figures in complaints as one (Catty 68). Even in John Trussell's The First Rape of Faire Hellen 
(1595), where Trussel "attempts to portray her [Helen] as a victim by having her tell the story of her rape by Theseus as a young girl ... the poem ends by looking towards her subsequent fall [her second 'rape']" (Catty 68-69). Catty asserts that "the contrast between Hellen and Lucrece concerns the course of action taken by the raped woman"(69):

Hellen's marriage [to her rapest], in her view, 'covers' her rape, so that she is 'enfranchiz'd from all feare of shame' (874). Yet Schmitz has suggested that her concern with appearances brings Hellen in line with the courtesans whose complaints emphasise cosmetics.... Throughout the poem, the idea of concealment or covering clashes with that of disclosure in connection with both rape and narrative. (Catty 68-70)

Helen's incessant attempts at concealment, of course, clash with Lucrece's/Lucrece's incessant exposures.

Lucrece, then, no doubt fervently disengages herself from the "paradigmatic," raped/ravished woman, because of the controversy surrounding Helen and her highly ambiguous reputation. According to Mihoko Suzuki, the fall of Troy, "as the myth of national origins for Western Europe, became a secular Fall; accordingly, Helen attained the status of a secular Eve. Like Eve and Pandora, Helen became a type of all women who bring woe to man" (13). She has become the prototype of the adulterous, libidinous woman-Aphrodite's surrogate—whose shame often overshadows even her infamous beauty. Indeed, concupiscence is such an integral part of Helen's mythopoeia, that Norman Austin claims even her patronymic required editing by Homer to avoid the connotations associated with her name:

The Homeric poems omit any reference to Helen's earthly father, Tyndareus; instead, she is invariably 'the daughter of Zeus.' This omission may be a calculated strategy on the part of the epic tradition to play down the promiscuity that figures in the Helen myth.... Other poets lose no 
chance to remark that Tyndareus was singularly unfortunate, cursed even, to be the father of singularly promiscuous daughters-Helen and Klytaimenstra being the two most memorable (15).

Accordingly, all preliminary references, in $D F$, to lurid pleasures seem to intersect in Helen-to her shame as an adulterous woe-man. Pride, for example, "creeps into every corner of a wench" (2.3.112). Lechery, or "Mistress Minx," "loves an inch of raw mutton better than an ell of fried stockfish" (2.3.159-60). And even Lucifer adds to the antifeminist jokes with: "Think of the devil, / And of his dame, too" (2.3.92-3). When Faustus requests a wife because he is "wanton and lascivious and cannot / live without a wife" (2.2.143-45), Mephistopheles responds that "marriage is but a ceremonial toy"(2.1.150):

I'll cut thee out the fairest courtesans And bring them every morning to thy bed.

She whom thine eye shall like, thy heart shall have, Were she as chaste as was Penelope, As wise as Saba, or as beautiful

As was bright Lucifer before his fall. (2.1.152-57)

Within this categorization of superlatives, the reader was, of course, expecting, "as beautiful as was" Helen, but she is already superimposed by the devil himself.

In Book XII of The Metamorphoses, Ovid refers to Paris who "Eloped with a young bride, seduced her, stole her, / Which opened a long war against the Trojans" (325). Ovid, writing in 8A.D. already makes explicit the doubleness that pervaded Helen's legend. Within one sentence he claims that she both eloped with Paris (of her free-will) and was seduced and stolen by him. This irreconcilability between Helen as victim and Helen as culprit—an embodiment of the virgin versus whore dichotomy of feminist criticism—-pervades both the Homeric poems and the post-Homeric 
emendations. According to Suzuki, "For some, Helen is a goddess, for others a grief; she is never a mere woman but one exalted or sinister, beyond the ordinary, the real" (35).

Most of the Iliadic revisions were, in essence, an attempt to underscore either Helen's accountability or her innocence. Herodotus asserts in Book I of his Histories, that: "Helen was not abducted by Paris but eloped with him willingly, and that the Greeks should not have launched a war to reclaim her: a woman would not be carried away unless she wished to be" (Suzuki 14). Herodotus, as Suzuki maintains, may be addressing "the question of Helen's motivation and responsibility-Was she a subject or an object?-a question raised but never explicitly answered in the Iliad" (14). However, at the same time, his misogynistic conviction, that she could not have been ravished unless she willed it, already makes his opinion of Helen undeniably clear.

Norman Austin likewise attempts to tackle this interminable question of culpability in Helen of Troy and her Shameless Phantom. According to him, "the portrait of Helen as it was transmitted through the tradition ... culminated in the Homeric poems-the woman who disgraced herself and betrayed her family and people. In the post-Homeric literary tradition Helen is again and again reviled, whether as the treacherous wife or as the libertine who preferred pleasure to honor" ([emphasis added] 2). It is therefore not surprising that Lucrece is convinced Helen lusted after Paris and that the unnecessary deaths caused by the war were a result of her private pleasure:

'Why should the private pleasure of some one Become the public plague of many moe?

Let sin alone committed, light alone Upon his head that hath transgressed so; Let guiltless souls be freed from guilty woe.

For one's offence why should so many fall, To plague a private sin in general? (Shakespeare, Lucrece 1478-484) 
Understandably then, one of Lucrece's most prevailing fears is how her tale, like Helen's, will be told/interpreted. Part of the reason she is alarmed is because she dreads that through such storytelling, she will forever be intertwined, not only with Tarquin, but with ignominy:

'The nurse to still her child will tell my story, And fright her crying babe with Tarquin's name.

The orator to deck his oratory

Will couple my reproach to Tarquin's shame.

Feast-finding minstrels tuning my defame,

Will tie the hearers to attend each line,

How Tarquin wronged me, I Collantine.

(Shakespeare, Lucrece 813-19)

She does not want others to tell her tale; instead, she prefers to tell it herself-for in telling her own tale she has the power to sway her audience and hence avoid Helen's fate: “"we will unfold / To creatures stern, sad tunes to change their kinds" (Shakespeare, Lucrece1146-147). Though Lucrece's rape is "to prove endlessly re-readable and open to interpretation," her theatrical suicide implies not only "an awareness of herself as text" (Catty 16), but a desire to maintain authorship over that text. In other words, she will not be written by others, she will write/right herself.

When Faustus asks Mephistopheles where hell is located, the demon responds:

Hell hath no limits, nor is circumscribed In one self place, but where we are is hell, And where hell is there must we ever be. And, to be short, when all the world dissolves, And every creature shall be purified, All places shall be hell that is not heaven. (2.1.124-29).

While heaven is where Lucrece is, in Faustus, hell is where Hell/en is. Unlike

Shakespeare, who exposes Lucrece's body, Marlowe strips Helen of a body, which helps 
to blame her-now completely without body, without a corporeal attachment to the mortal world, she is a demonic spirit. According to Bevington and Rasmussen:

When the Evil Angel insists to Faustus that 'Thou art a spirit. G-d cannot pity thee' (II.iii.13), he seems to argue an inflexible link between being a 'spirit' and being irrevocably damned. Helen too is a spirit, Greg notes, and so when Faustus takes her as his paramour he commits the sin of demoniality, or bodily intercourse with demons, thereby confirming his state of irredeemable depravity. Roma Gill, accepting Greg's argument in the main but noting that the Old Man does not give up in his attempts to counsel Faustus until Faustus vows to take Helen as his paramour (V.i.110 ff.), argues that the moment of irreversible damnation occurs precisely at this point. (Marlowe 19)

In Shakespeare's "Sonnet 129," the speaker claims, about lust, that "none knows well / To shun the heaven that leads men to this hell" (13-14). The same idea is propounded in Titus, when Demetrius says "till I find the stream / To cool this heat, a charm to calm these fits, / Per stygia, per manes vehor" (1.1.633-35)—which the footnote translates as "I am in hell" (Shakespeare, Titus 166). While in Lucrece lust leads Tarquin to this metaphorical hell, in $D F$, the metaphor is actualized.

Jonathan Bate's discussion of the figure of Tamora, in Titus Andronicus, is applicable to Marlowe's Helen. Bate deftly notes that "if woman is not silenced and mutilated, then she must be demonized, as she is in the figure of Tamora" (Shakespeare, Titus 37):

Heinrich Heine noticed the way in which 'Shakespeare places two women of entirely different moulds next to one another, in order that we may read their characters by the force of contrast' (Romantics, 544). Are not such contrasts typical of a male need to cast all women as virgins or whores? (Shakespeare, Titus 37)

Indeed, Shakespeare seems to transplant the demonic, whorish Helen of $D F$ into his poem to use her as a mark of contrast to the heavenly, "virgin" Lucrece. Again, though 
somewhat surprising, it is a focus on, not a religious denial of, corporeality, which assures Lucrece of her role as "virgin" in the dichotomy.

When, at the beginning of the play Faustus states: "Sweet Analytics, 'tis thou hast ravished me!" (1.1.6), and "'Tis magic, magic that hath ravished me" (1.1.102-4), he sets himself up for comparison with the most famous ravished woman of antiquity. Faustus is supposedly ravished by necromancy, Helen of Troy by erotic desire embodied in the figure of Paris. But, Helen serves, not only as a reflection of the disembodied/dismembered Faustus, she is the very symbol of his disembodiment, his metamorphosis into a spirit/demon.

The daemonic Helen, in the Classical sense as a secondary divinity between the gods and man, is a result, to a large extent, of Stesichorus's revision: "Greek myths abounded in variants, and the story that Stesichorus told, of Helen replaced by a ghost of herself at Troy, may have been such a variant, perhaps promulgated by the devotees of Helen's shrine at Therapne in Sparta, where Helen continued to be worshipped as a goddess into the historical period" (Austin 3). The source for the story behind Stesichorus's Palinode is Plato, who claims that Stesichorus

was deprived of his sight for his slander (kategoria) of Helen. He did not remain in ignorance ... he understood the cause of his blindness and composed 'the so-called Palinode' (that is, his 'song re-sung,' his recantation), whereupon his sight was restored. ... The Trojan war, thus revised, became a war not for a woman but for her ghost, shadow, or image - the various meanings contained in the Greek word eidolon. (Austin 3)

Helen's eidolon has significance in $D F$ since she appears in the form of a spirit. Ironically, though Stesichorus's disembodiment of Helen is an attempt to defend her innocence, Marlowe's disembodiment of Helen is a clear sign of her condemnation. She 
is no longer a daemon; she is a demon. It is as if, without a body, one letter, alone, is enough to transform a glorified Helen into a damned Helen.

Helen is de-corporealized in the play; however, she is demonized, not apotheosized. The simple fact that Mephistopheles, who has no power in the realm of G-d, is able to summon her, is proof of her fate. She is damned not only because her "ghost be with the old philosophers" (1.3.59)-i.e., as a Classical, pre-Judeo Christian figure, she cannot enter heaven—but because of her sexual infidelity. Apparently both Marlowe and Shakespeare draw upon a pre-Palinode version of a disgraced and disgraceful Helen. Such versions indicate that even in Sparta, where according to the Odyssey Helen and Menelaus were supposed to live in immortal bliss, there is an undercurrent of sorrow: "Sparta, as portrayed in the Odyssey, bears resemblances to the underworld, as scholars have remarked, and Helen bears resemblance to Persephone" (Austin 19). Like Persephone, Helen is the devil's "dam" (DF 2.3.95).

The mute Helen that appears in $D F$ was brought by Paris, according to Faustus, like the other "spoils to rich Dardania" ([my emphasis] 5.1.25); hence, she is, like Lucrece, commodified as booty. However, she also serves, through her "sweet embraces," to "extinguish clear" Faustus's thoughts that dissuade him from keeping his pact with Lucifer (5.1.88-91). Just as she "was the admirablest lady that ever lived"-a "peerless dame ... whom all the world admires for majesty" (5.1.13-16)—so too is she the soul-sucking vampiress. But, Helen is still the "beautifullest in all the world" (5.1.11); in fact, she is not only beautiful herself, but has the power to beautify others. According to Austin, "Herodotus tells a lovely story of this Helen [of the local Spartan cult], the goddess, beautifying an ugly child, who grew up to become the mother or the 
Spartan king Demaratos" (32). If Helen did such for a child, could she not do the same for hell? Faustus claims that she is "fairer than the evening's air, / Clad in the beauty of a thousand stars"(5.1.107-8):

Brighter . . than flaming Jupiter

When he appeared to hapless Semele, More lovely than the monarch of the sky In wanton Arethusa's azure arms; And none but thou shalt be my paramour. (5.1.109-113).

All references are Classical, Faustus evokes Jupiter in lieu of G-d, yet, does it not follow that she is more lovely than G-d and heaven itself? And yet, as "Jean-Pierre Vernant says of Helen: 'She who is "most beautiful" also incarnates horrible Erinys, the savage and murderous Ker. In her desire and death are joined and intimately mixed"' (Suzuki Footnote 21).

Though Helen weaves, her subject-the war which resulted from her ravishment/elopement-severs her from the likes of Philomela or Penelope. According to Catty, "her weaving/language can . . connote promiscuity, balancing the other myths in which language or weaving is a resistance of male tyranny" (123)."Another association of the web," asserts Catty, "is with witchcraft" (123). Hence, besides all other dichotomies that saturate the Helen myths, is her division into healer and sorceress, the import of which is conspicuous in conjunction with $D F$. According to Austin, when Telemachus visits Sparta and his sorrowful recollections dampen the occasion, Helen drops the pharmakon nephenthes into the wine and hence brings about a "charming" (literally) amnesia (75):

The Helen who is treated in the Iliad as if she were the cause of the Trojan War [with her be-"witching" effect upon man, i.e., as the cause of innumerable deaths] has now become the healer, whose analgesic 
medication, in Homer's description, will let a man bear the death of father or mother without grief, and even let him witness his dear brother or son cut down by the sword before his eyes. (76)

Helen, according to the Odyssey, acquired the medicine from Polydamna, when she and Menelaus were grounded in Egypt after being blown off course on their return from Troy:

Egypt was as famed in Homer's time, it seems, for its ancient and occult learning as it is in our own time, when the theme of Helen in Egypt has inspired an opera-Die agyptische Helena, by Gofmannsthal and Strauss-and a long lyric poem-Helen in Egypt-by the American imagist poet H.D. In Homer, Egypt is the medical capital of the world: 'There the fertile soil grows medicines [pharmaka] in the greatest number, many good, when mixed, and many grievous. In Egypt every person is a physician, for they are sprung from the stock of Paian, the Healer' (4.22732)... . The Odyssey has deftly translated Helen's magic into a medical skill. If Helen has the powers of a dread goddess, she is also no Circe mixing dangerous drugs in the forest primeval. She has become a learned physician. ... The medicines of Polydamna ... are a reification of Helen's own mind-altering powers (Austin 75-77).

However, though Helen seems at once a healer and a witch, her drugs are more wicked than salubrious since they only relieve by anesthetizing/zombifying. Helen does the same for Faustus, she helps him forget the hell he is about to enter. Shakespeare's Richard III, is ready "to undertake the death of all the world" so that he "might live one hour" in Anne's "sweet bosom" (2.1.126-27); likewise, Faustus, with a carpe-diem sentiment, is ready to accept/forget eternal damnation to presently enjoy his fair Helen.

In Bruce E. Brandt's article "Marlowe's Helen and the Soul-in-the-Kiss Conceit," he claims that: "The soul-in-the-kiss topos was widespread in the ancient world, but with the coming of Christianity it acquired new meanings. Foremost among these is the kiss of peace, a ritualized greeting ... symbolizing unity and concord with the church" (119). The ironic inversion in $D F$ symbolizes Faustus's disconnection from the Christian church (Brandt 119): 
Sweet Helen, make me immortal with a kiss.

Her lips suck forth my soul. See where it flies!

[They kiss.]

Come Helen, come, give me my soul again.

Here will I dwell, for heaven is in these lips,

[They kiss again.]

And all is dross that is not Helena. (5.1.96-100)

This soul-in-the-kiss conceit was meant to represent the unification of the souls with the divine; Helen's kiss, however, "confirms him [Faustus] on his path to damnation" (Brandt 119). Religion is, of course, relevant. However, what Brandt does not venture to say, and what seems the most consequential, is that since, through the kiss, one soul came to support two bodies, Faustus and Helen are now, not only indiscriminate personas, but are damned by the same fate. Indeed, When Fredrick asks of Faustus: "Was this that stern aspect, that awful frown, / Made the grim monarch of infernal spirits / Tremble and quake at his commanding charms? (4.2.46-8), one can not help but draw an immediate correlation to Helen: "Was this the face that launched a thousand ships / And burnt the topless towers of Ilium?" (5.1.94-5). Both Faustus and Helen are now only identifiable by their iniquities.

When Faustus asks Mephistopheles, early in the play, why Lucifer tempts the human soul, his response is "Solamen miseris socios habuisse doloris," or as the footnote indicates, "Misery loves Company" (2.1.42). Though, at first, this obfuscation seems little more than a convenient way to avoid the theological question, it actually explains, not only why Faustus was beguiled, but more importantly, the significance of Helen's anomalous presence in the play. Both Faustus and Helen must live-eternally—under the shadow of a transgression: for Faustus it was his concession to the forces of the dark, for Helen capitulation to adultery. Their sins signify acquiescence to passion: intellectual or 
sexual. Both characters were renowned in good light before their "fall," but after, became infamous as malefactors. Faustus and Helen, both in hell, at least according to Marlowe, can at least now share each other's shame in a misery that loves company.

It is precisely this company that Lucrece attempts, through suicide, to avoid. And, while Shakespeare depicts Lucrece as heavenly, she is never truly more than a woman. Shakespeare's focus on corporeal images assures that, unlike Helen, Lucrece never becomes a spirit, and hence, never has to fear the awesome power of one "letter."

\section{Conclusion:}

Modern women may read The Rape of Lucrece as a celebration of "womanly weakness." On the surface, Lucrece appears exaggeratedly, and mockingly, moralistic, whiny, and dull. Futhermore, Lucrece hardly seems worthy of accolade, for perpetuating severely-limited gender roles, for choosing self-abnegation over revenge, and for complaining, without end, to no end. For a first time reader, Lucrece is definitely not one of Shakespeare's more engaging, or feministic, works. A second time reader, however, may feel differently.

Two exercises helped me understand Lucrece's predicament, and appreciate her subtle power in the face of a culture and period very different from our own. The first was a study of Shakespeare's sources. After reading how tradition typically penned/penned Lucrece, I gained a new-found respect for Shakespeare's Lucrece. Shakespeare's sources objectified Lucrece in order to eradicate any doubts as to her innocence. In other words, though they were working on her behalf, the issue became, very much, a double-edged sword. If Lucrece was portrayed as an individual with her 
own will, then she could also will the rape. If subjectivity, on the other hand, was decorticated, then there was no means by which to condemn her. They may have praised Lucrece, but only as a symbol, only as an emblem of chastity to be worn on a woman's lapel. Shakespeare's version, on the other hand, labored to prove that she could retain her autonomy along with her inculpability. Shakespeare's audience, participating in the voyeurism of the rape scene, could at least testify on Lucrece's account. Furthermore, unlike his sources, Shakespeare lets Lucrece rant, lets her act, lets her tear a tapestry, lets her react as a wronged woman undoubtedly would.

The second exercise, that helped redeem Lucrece in my mind, was an investigation into the piece-meal body. Feminist critics, such as Nancy J. Vickers, have argued that the voyeurism and metaphorical dismemberment inherent in the blazon is affiliated with, even engenders, rape. Accordingly, the segmented female body, is often associated with the objectification and violence inherent in male desire. In Shakespeare's poem, on the other hand, the female body in parts is a body of power. A new figure, like the mythic Phoenix, emerges out of the scattered body parts, and arises from its own ashes. It is a hybrid female body composed of an Amazonian breast, an eye from Medusa and another from Christ, Philomela's tongue, a martyr's hand, and a strong sense of selfidentity. Lucrece never fully abandons herself to the woods of violent Bacchic-type revenge; she never becomes a "wild woman." But she never becomes a "weak woman" either. Her power is manifested in the sphere of Roman society, but she does not depend upon that society or its laws. She moves cautiously between the two realms. She exists, always, in the space between the two extreme pendulum positions. 
Lucrece's manipulation of spectacle and theatrics, in the performance of her own revenge, helps her retain authorship over her body/text; By "writing” her own tale, Lucrece secures her virtuous reputation in posterity, and hence, never becomes a Helen. Helen of Troy is what happens when a story is mis-read and mis-interpreted, specifically a story about rape. For all the emendations that strove to exonerate her, the seepage, the drip, of her foul, or at best ambiguous, reputation could not be soaked up. Her reputation watermarks any work that so much as mentions her name, even a work that itself deals with the rape of a woman.

Shakespeare includes Helen in the ekphrasis of the tapestry; and while it is Lucrece (and not the narrator) who denounces her, it is Shakespeare who posits Lucrece as an anti-Helen by focusing on his heroine's corporeality. Stesichorus's attempt to apotheosize Helen through his eidolon revision only resulted in her demonization in Marlowe's Doctor Faustus. In other words, to disembody a raped woman is to create a transient spirit—one which could easily cross the boundary between glorification and damnation. Lucrece may be heavenly, but she is not heaven. She is as much body as she is spirit. Shakespeare may fragment her body; however, fragmentation, according to Hillman and Mazzio, was "not always a source of anxiety":

Any reading of cultural pathologies implicit in the decontextualized or dramatically foregrounded organ would also have to consider the more normative models of bodily partition that would, for example, enable the queen of England to be officially represented (in the famous 'Rainbow Portrait') wearing a gown covered with eyes, ears, and mouths, or enable an early modern religious order, 'the Cult of the Sacred Heart,' to be organized around a single body part. (Mazzio xvii) 
Thomas Middleton's ghost complaint, The Ghost of Lucrece, is an example of what can happen when a wronged woman is de-corporealized. In Middleton's poem, Lucrece has literally come from Hell to plead her case-she is vicious, whorish, and utterly unlike the chaste, if somewhat self-congratulatory and dull, Lucrece we know from Shakespeare. To disembody Lucrece is to literally create another Faustus, another Helen-all three residing in an Underworld of shame, hubris, and licentiousness. Shakespeare's Lucrece does not belong in their company. Like Faustus and Helen, she "engages in a moral struggle," but unlike the other two, does find "a way to oppose and overcome the evil that entraps her" (Bromley 201). That way involves retaining personal power in a world that is ready to commodify and objectify her as a symbol. 
Austin, Norman. Helen of Troy and her Shameless Phantom. Ithaca: Cornell UP, 1994.

Baines, Barbara J. "Effacing Rape in Early Modern Representations." ELH 65.1 (1998): 69-98.

Bloom, Harold. The Anxiety of Influence. $2^{\text {nd }}$ ed. Oxford: Oxford UP, 1997.

Brandt, Bruce E. "Marlowe's Helen and the Soul-in-the-Kiss Conceit." Philological Quarterly 64 (Winter 85): 118-21.

Bromley, Laura G. “Lucrece's Re-Creation.” Shakespeare Quarterly 34.2

(Summer 1983): 200-11.

Catty, Jocelyn. Writing Rape, Writing Women in Early Modern England:

Unbridled Speech. Early Modern Literature in History. Ed. Cedric C. Brown.

New York: St. Martin's P, 1999.

Chaucer, Geoffrey. The Legend of Good Women. Trans. Ann McMillan. Houston: Rice UP, 1987.

Daniel, Samuel. "The Complaint of Rosamund." The Complete Works in Verse and Prose of Samuel Daniel. Ed. Rev. Alexander B. Grosart. New York:

Russell \& Russell, 1963. 79-113.

Donaldson, Ian. The Rapes of Lucretia: A Myth and its Transformations. Oxford: Clarendon P, 1982.

Fantham, Elaine et al. Women in the Classical World: Image and Text. New York: Oxford UP, 1994.

Laqueur, Thomas. Making Sex: Body and Gender from the Greeks to Freud. Cambridge: Harvard UP, 1990.

Livy. The Early History of Rome: Books I-V of The History of Rome from its Foundation. Trans. Aubrey De Selincourt. Intro. by R.M. Ogilvie. New York: Penguin Books, 1971.

Marlowe, Christopher. Doctor Faustus. The Revels Plays. Ed. David Bevington and Eric Rasmussen. New York: Manchester UP, 1993.

-----. Tamburlaine. The New Mermaids. Ed. Anthony B. Dawson. New York: W.W. Norton,1997. 
Maus, Katharine Eisaman. "Taking Tropes Seriously: Language and Violence in Shakespeare's Rape of Lucrece." Shakespeare Quarterly 37.1 (Spring 1986): 66-82.

Mazzio, Carla and David Hillman, eds. The Body in Parts: Fantasies of Corporeality in Early Modern Europe. New York: Routledge, 1997.

Moore, Stephen. G-d's Gym: Divine Male Bodies of the Bible. New York:

Routledge, 1996.

Newman, Jane O. “'And Let Mild Women to Him Lose Their Mildness': Philomela, Female Violence, and Shakespeare's The Rape of Lucrece." Shakespeare Quarterly 45.3 (Fall 1994): 304-26.

Ovid. Fasti: Roman Holidays. Trans. and edited by Betty Rose Nagle. Bloomington: Indiana UP, 1995. 75-80.

-----. Heroides. Trans. Harold Isbell. New York: Penguin, 1990.

----.The Metamorphoses. Trans. Horace Gregory. New York:

The Viking Press, 1958.

Scott, Grant F. The Sculpted Word: Keats, Ekphrasis, and the Visual Arts. Hanover: UP of New England, 1994.

Shakespeare, William. "The Rape of Lucrece." The Poems. The Arden Shakespeare. Ed. F.T. Prince. New York: Routledge, 1996.

----. "Sonnet 129." The Norton Shakespeare. Ed. Stephen Greenblatt. New York: W.W. Norton Co., 1997. 1967.

----. Richard III. Ed. David Bevington. New York: Bantam Books, 1988.

----. Titus Andronicus.. The Arden Shakespeare. Ed. Jonathan Bate. New York: Routledge, 1995.

Suzuki, Mihoko. Metamorphoses of Helen: Authority, Difference, and the Epic. Ithaca: Cornell UP, 1989.

Tilley, Maureen A. and Susan A. Ross, eds. Broken and Whole: Essays on Religion and the Body. New York: UP of America, 1995.

Vickers, Nancy J. “This Heraldry in Lucrece' Face.” Poetics Today 6.1-2 (1985): 171-84. 
Woodbridge, Linda. "Palisading the Elizabethan Body Politic."

Texas Studies in Literature and Language 33.3 (1991 Fall): 327-54.

Wordsworth, Charles. Shakespeare's Knowledge and Use of the Bible. $3^{\text {rd }}$ ed. New York: AMS Press Inc., 1973. 